UNIVERSIDADE DE BRASÍLIA

INSTITUTO DE CIÊNCIAS BIOLÓGICAS

DEPARTAMENTO DE BIOLOGIA CELULAR

PÓS - GRADUAÇÃO EM BIOLOGIA MOLECULAR

Construção e produção de fragmentos de anticorpos anti-ssDNA em um contexto de desenvolvimento de linfócitos $B$

RONNY PETTERSON DOS SANTOS ARAUJO

Orientador: Dr. MARCELO DE MACEDO BRÍGIDO

Brasília - DF

2016 


\author{
UNIVERSIDADE DE BRASÍLIA \\ INSTITUTO DE CIÊNCIAS BIOLÓGICAS \\ DEPARTAMENTO DE BIOLOGIA CELULAR \\ PROGRAMA DE PÓS-GRADUAÇÃO EM BIOLOGIA MOLECULAR
}

\title{
Construção e produção de fragmentos de anticorpos anti- sSDNA em um contexto de desenvolvimento de linfócitos B
}

RONNY PETTERSON DOS SANTOS ARAUJO

Orientador: Dr. MARCELO DE MACEDO BRIGIDO

Dissertação apresentada ao Departamento de Biologia Celular do Instituto de Ciências Biológicas da Universidade de Brasília como Requisito parcial à obtenção do grau de Mestre em Biologia Molecular. 
Banca examinadora:

Prof.Dr. MARCELO DE MACEDO BRÍGIDO (UnB - Presidente/Orientador) $\operatorname{Prof}^{\mathrm{a}}{ }^{\mathrm{Dr}}{ }^{\mathrm{a}}$. KELLY GRACE MAGALHÃES (UnB - Membro Interno)

Prof.Dr. NAPOLEÃO FONSECA VALADARES (UnB - Membro externo) 


\section{Agradecimentos}

Queria agradecer aos meus pais, Francisco da Chagas e Eliane Maria pelo apoio, suporte e compreensão durante toda a vida.

Ao Professor Marcelo Brígido e a Professora Andrea Maranhão pela oportunidade que me foi dada, pela confiança e pelos ensinamentos que com certeza me ajudaram amadurecer ainda mais.

Ao Professor Napoleão Valadares pelas dicas valiosas e por ceder os equipamentos necessários para o desenvolvimento de alguns experimentos.

Aos meus irmãos, Emerson Chagas, Danielle Araujo e Ingridy Juliana pelo companheirismo ao longo dos anos.

Aos meus familiares de Brasília Tia Leila, meus primos Marcos Henrique e Helder Castro, meu avô e sua esposa, Dona Aparecida) que me receberam de braços abertos quando iniciei essa nova etapa, tornando essa transição bem mais fácil e agradável.

Aos meus amigos e companheiros de laboratório durante esses anos, Rafael Burtet, Juan Riascos, Maryani Bezerra, Jhennipher Lana, Nestor Leyton, Isabel Sousa, Manuela Maragno, Thompson Tomatieli, Maria José, Laura Miazato, Carla Sottomaior, Ana Paula, Galina Gulis, Juliana Almeida, Fernanda Bento, Rafaella Côrrea, Adryelle Gonçalves. Muito obrigado pessoal pela ajuda, dicas nos experimentos e risadas proporcionadas! Esse trabalho também foi construído pelas mãos de muitos de vocês. Valeu!

Aos meus amigos Rodolfo Ritchelle, Erasmo Veloso, Marcos Pollo, Arielson Carvalho, Tácito Felipe, Laíze Lemos, Isabelly Meneses, Massaine Bandeira, Alisson Dantas, dessa longa estrada chamada vida, com alguns ai já se vão o que... 19 anos! Obrigado pela amizade pessoal, pelas palavras de incentivo, querendo ou não (hahaha) vocês têm parte nisso.

Aos funcionários do IB sempre prestativos e eficientes para resolver qualquer problema. Especialmente, a dona Fátima e dona Ivonildes que diariamente estavam nos auxiliando.

As agências de fomento: Conselho Nacional de Desenvolvimento Científico e Tecnológico (CNPq) e a Fundação de Amparo à Pesquisa do Distrito Federal (FAP-DF) que forneceram o apoio necessário para o desenvolvimento deste trabalho. 


\section{Sumário}

\section{Lista de Figuras}

\section{Lista de Tabelas}

\section{Lista de Abreviaturas}

\section{Resumo}

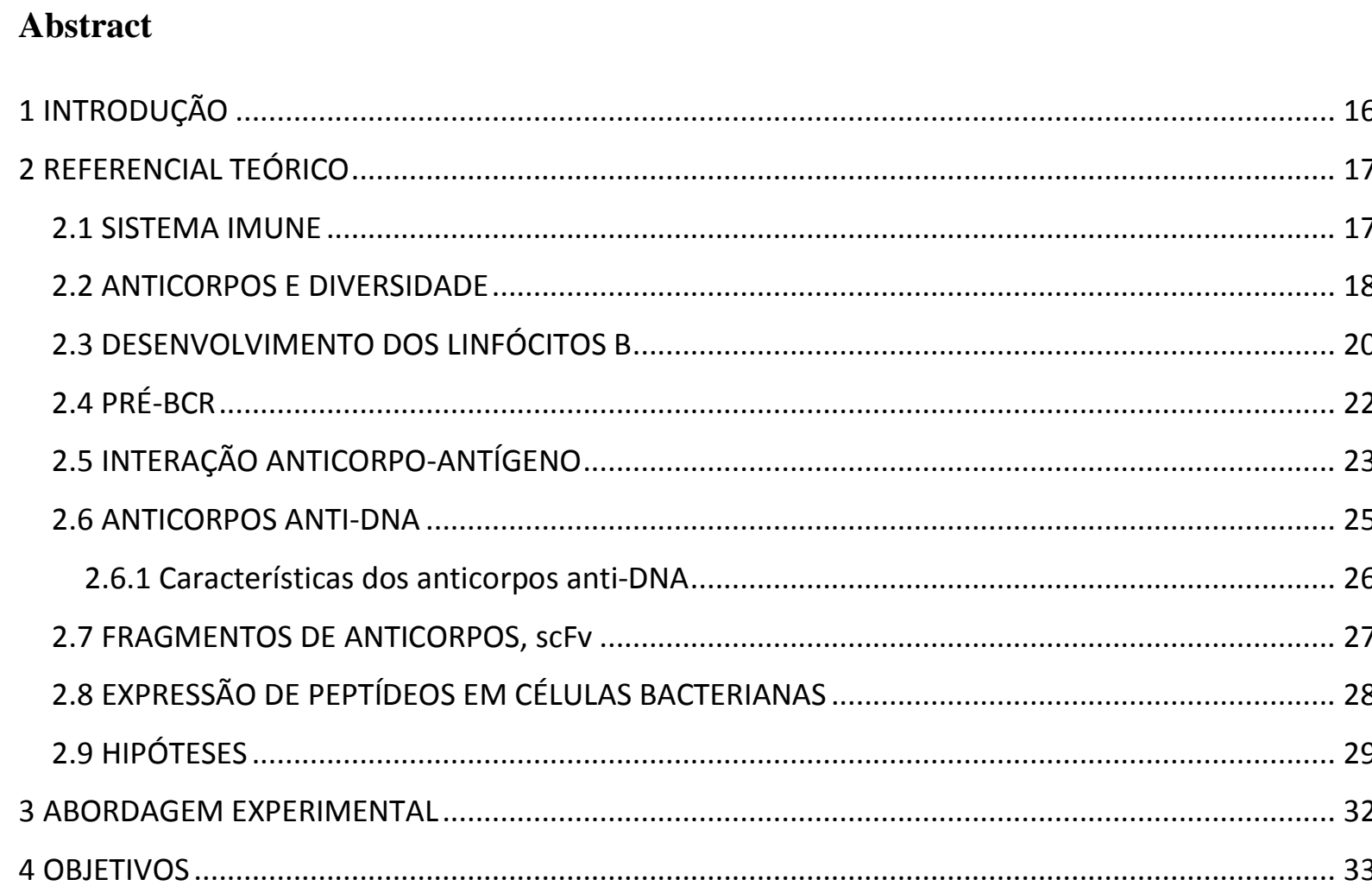

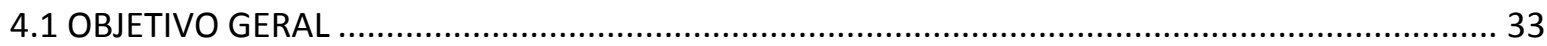

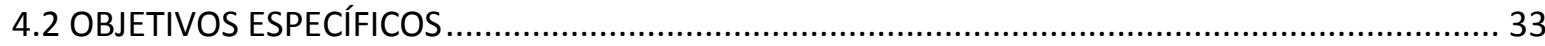

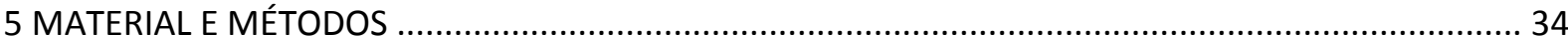

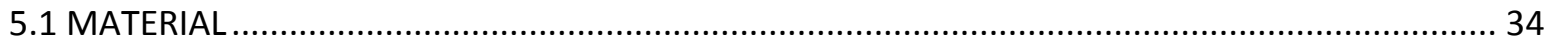

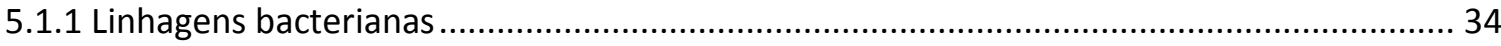

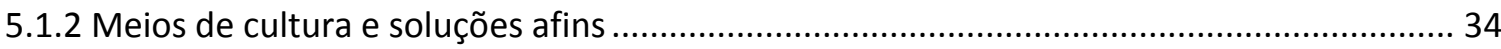

5.1.3 Soluções para extração de DNA plasmidial caseira................................................... 35

5.1.4 Soluções e reagentes para eletroforese em gel de agarose e poliacrilamida.................... 37

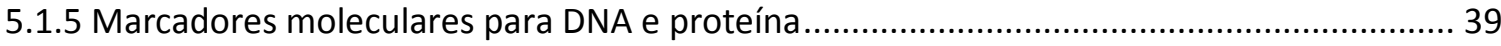

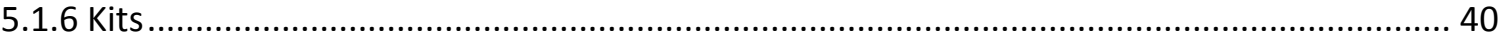

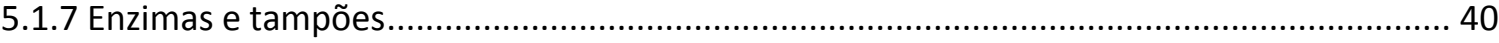


5.1.8 Soluções para células eletrocompetentes e choque térmico 40

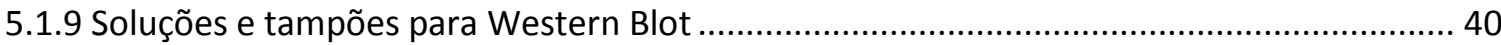

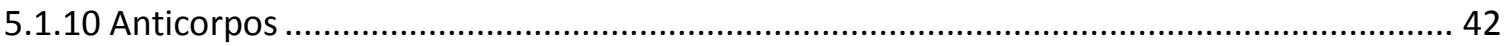

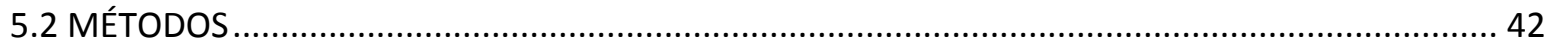

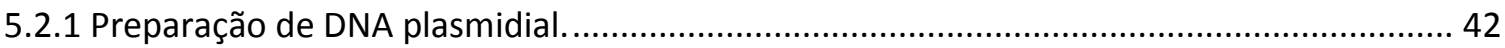

5.2.2 Preparação de células competentes e transformação bacteriana. ..................................... 43

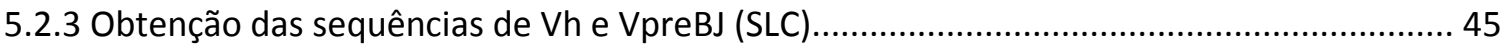

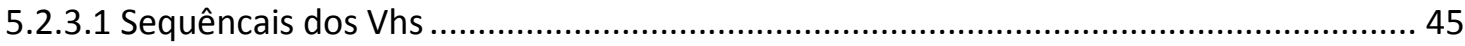

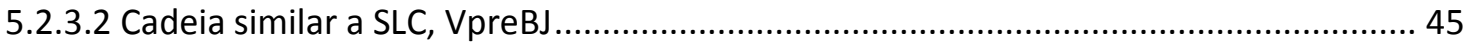

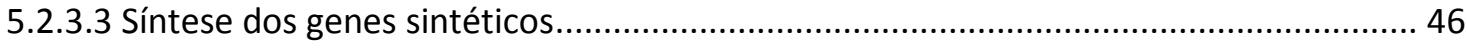

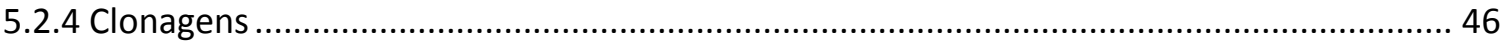

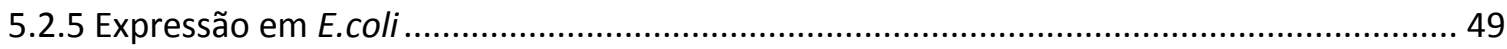

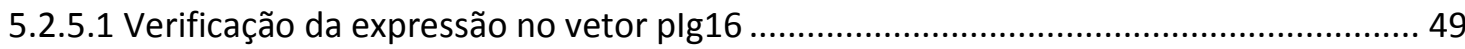

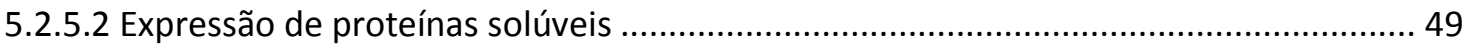

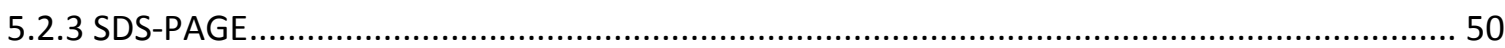

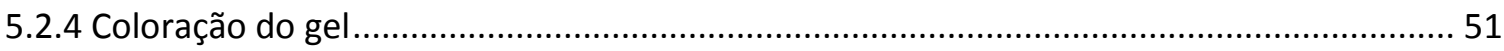

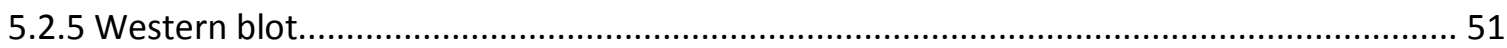

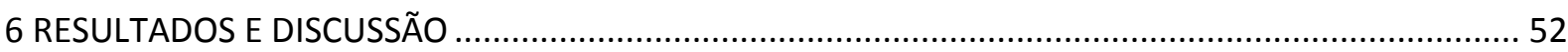

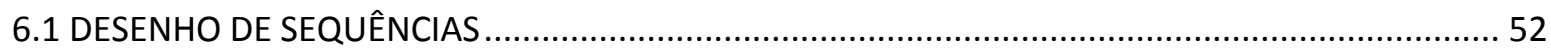

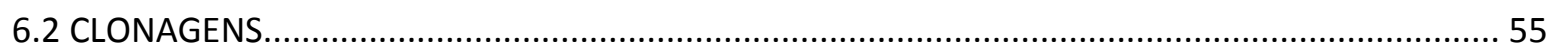

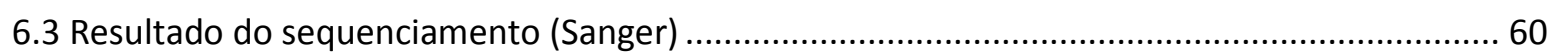

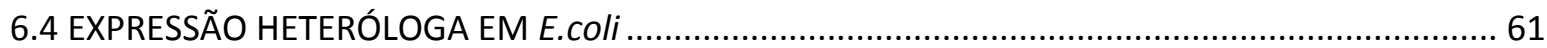

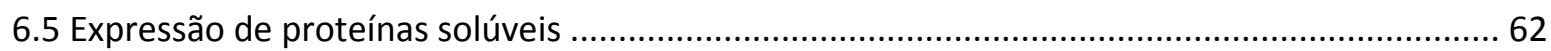

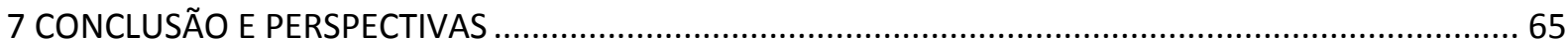

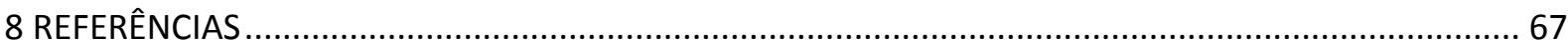




\section{Lista de Figuras}

Figura 1. Desenho esquemático da estrutura de um anticorpo.

Figura 2. Representação esquemática da formação das cadeias leve e pesadas das imunoglobulinas pela união dos segmentos gênicos $\mathrm{V}$ e J (cadeia leve) e V, D e J (cadeia pesada).

Figura 3. Etapas do desenvolvimento dos linfócitos B.

Figura 4. Representação esquemática do pré-BCR e do BCR.

Figura 5. Representação da ligação estabelecida entre as regiões de um scFv e seu antígeno alvo.

Figura 6. Desenho esquemático de anticorpo inteiro e um fragmento scFv.

Figura 7. Modelo generalizado do scFvs produzidos.

Figura 8. Representação esquemática da abordagem experimental.

Figura 9: Construções dos genes das famílias VH10 e VH4 e suas variantes de CDR H2 trocadas.

Figura 10. Alinhamento múltiplo (ClustalW/Bioedit) das sequências de germinais das famílias VH4 e VH10 e suas variantes com as CDRs trocadas.

Figura 11: Esquema do desenho da cadeia leve (VpreBJ) expressa em células B murina em desenvolvimento com modificações conforme Morstadt et al (2008).

Figura 12. Esquema da primeira clonagem. Liberação do vetor e retirada do inserto com as enzimas XmaI e NcoI seguida da ligação para a formação de um novo plasmídeo (VH10).

Figura 13. Digestão dos plasmídeos dos plasmídeos para a confirmação da clonagem do VH10. 
Figura 14. Esquema do segundo conjunto digestões.

Figura 15. Digestão dos plasmídeos para a confirmação da clonagem de VH4.

Figura 16. Digestão dos plasmídeos para a confirmação da clonagem de VH4-H210.

Figura 17. Alinhamento múltiplo (ClustalW/Bioedit) das sequências resultantes da primeira clonagem (C2, C7 e C8) após sequenciamento Sanger e do vetor (pIg16).

Figura 18. Alinhamento múltiplo (ClustalW/Bioedit) das sequências resultantes do sequenciamento Sanger do segundo conjunto de clonagens (VH4; VH4-H210; VH10-H24).

Figura 19. Western blot. Expressão de VH10 (scFv), amostras do extrato celular total de 3 colônias.

Figura 20..SDS-PAGE e Western blot do extrato total de cepas de BL21(DE3) LysS com os plasmídeos VH4, VH4-H210 e VH10-H24.

Figura 21. SDS-PAGE das amostras tratadas para obtenção de fração solúvel de proteínas após a indução em diferentes concentrações de IPTG a $16^{\circ} \mathrm{C}$.

Figura 22. Western blot das amostras tratadas para obtenção de fração solúvel de proteínas após a indução em diferentes concentrações de IPTG a $16^{\circ} \mathrm{C}$.

Figura 23. SDS-PAGE das amostras tratadas para obtenção de fração solúvel de proteínas após a indução em diferentes concentrações de IPTG a $37^{\circ} \mathrm{C}$. 


\section{Lista de Tabelas}

Tabela 1: Análise das sequências de segmentos gênicos VH murinos depositados no banco de dados Genbank anotados quanto a especificidade.

Tabela 2. Sistema de digestão de plasmídeos provenientes de MidiPrep (QIAGEN).

Tabela 3. Sistemas de ligação utilizados nas clonagens. 


\title{
Listas de Termos e Abreviaturas
}

\author{
APS persulfato de amônio. \\ BCIP 5-bromo-4-cloro-indolil fosfato. \\ BCR receptor de células B maduras \\ $\mathrm{EtBr} \quad$ brometo de etídeo. \\ CDR região determinante de complementaridade. \\ CH domínios constantes da cadeia pesada de um anticorpo. \\ CL domínio constante da cadeia leve de um anticorpo. \\ C-terminal extremidade carboxi- terminal \\ dH2O água destilada \\ DNA ácido desoxirribonucleico. \\ EDTA ácido etilenodiaminotetracético. \\ ELISA ensaio de ligação imunoenzimática \\ Fab fragmento de anticorpo de ligação ao antígeno. \\ Fc fragmento cristalizável de anticorpo (porção constante). \\ Fv fragmento variável do anticorpo. \\ FW framework \\ g grama. \\ h hora. \\ Ig imunoglobulina. \\ IPTG isopropil-b-D-galactosídeo \\ $\mathrm{kb} \quad$ kilobase. \\ $\mathrm{KCl} \quad$ cloreto de potássio. \\ $\mathrm{kDa} \quad$ kilodaltons. \\ L litro. \\ LES lúpus eritematoso sistêmico
}


molar.

$\mathrm{mA}$ miliamper.

mg miligrama.

$\mathrm{MgCl} 2$ cloreto de Magnésio.

MgSO4 sulfato de Magnésio.

$\min \quad$ minuto.

$\mathrm{mL} \quad$ mililitro.

$\mathrm{mM}$ milimolar.

$\mathrm{NaCl} \quad$ cloreto de Sódio.

$\mathrm{NaOH} \quad$ hidróxido de Sódio.

NBT nitro Blue Tetrazole.

${ }^{\circ} \mathrm{C} \quad$ graus celsius.

DO 600 densidade ótica a 600ๆm.

ORF matriz de leitura aberta (open reading frame)

Ori origem de replicação.

$\mathrm{p} / \mathrm{v} \quad$ peso/volume.

pb pares de base.

PBS tampão fosfato - salina.

q.s.p. quantidade suficiente para.

RNAse ribonuclease.

Rpm rotações por minuto

$\mathrm{scFv}$ fragmento variável de anticorpo cadeia única

SDS sódio duodecil sulfato

SDS-PAGE eletroforese em gel de poliacrilamida/SDS

ssDNA DNA de fita simples

SLC cadeia leve substituta (surrogate light chain)

TE Tampão Tris/EDTA

TEMED N, N, N', N'- tetrametil etilenodimetilamina.

Tris-Base tris (hidroximetil)aminometano. 


$\begin{array}{ll}\text { UV } & \text { ultravioleta. } \\ \mathrm{V} & \text { volume. } \\ \mathrm{v} / \mathrm{v} & \text { volume/volume. } \\ \mathrm{VH} & \text { segmento V formador da cadeia variável pesada de um anticorpo. } \\ \mathrm{V}_{\mathrm{h}} & \text { domínio variável da cadeia pesada de um anticorpo. } \\ \mathrm{VL} & \text { domínio variável da cadeia leve de um anticorpo. } \\ \eta \mathrm{g} & \text { nanograma. } \\ \mu \mathrm{g} & \text { microgramas. } \\ \mu \mathrm{l} & \text { microlitros. } \\ \Omega & \text { ohm }\end{array}$




\section{RESUMO}

Os anticorpos anti-ácidos nucleicos são importantes no desenvolvimento de doenças autoimunes como o lúpus eritematoso sistêmico (LES). Porém, muito pouco se sabe sobre a origem e manutenção desses anticorpos pelo organismo e das interações desses anticorpos com seus antígenos. Foi observado na literatura e em trabalhos anteriores do grupo de Imunologia Molecular (UnB), que as sequências anotadas em banco de dados da família VH10 formadora da região variável da cadeia pesada de anticorpos era composta em sua maioria de sequências formadoras de moléculas anti-DNA. Além disso, através de uma abordagem experimental observou-se que essa família apresenta uma certa independência da CDR H3 para esta afinidade. Baseando-se nesses achados, nós desenhamos quatro fragmentos de anticorpos, no formato $\mathrm{scFv}$ (single-chain fragment variable), fragmento que preserva o sítio de ligação ao antígeno, composto de uma cadeia pesada (VH) ligada a uma cadeia leve, conhecida surrogate light chain (SLC) na tentativa de simular o reconhecimento antigênico em momento específico do desenvolvimento dos linfócitos $\mathrm{B}$, onde a auto-reatividade é usada em prol do desenvolvimento normal dessas células. Levando-se também em conta a independência da CDR H3 para a ligação ao antígeno, nós iremos avaliar também através dessas construções o papel da CDR H2 para a ligação. Após clonagem das sequências em plasmídeo para a expressão heteróloga, esses scFvs foram produzidos em cepas de Escherichia coli BL21(DE3) pLysS. Até o momento, após padronização das condições para a produção de scFvs solúveis, condições favoráveis de duas das quatro construções foram estabelecidas. Estas construções irão permitir a análise do papel do segmento gênico $\mathrm{V}$, mais especificamente da CDR2, para a afinidade ao DNA por anticorpos originados do segmento germinal de VH10. Além disso, será possível simular a interação antigênica de cadeias pesadas auto-reativas e não auto-reativas em um momento específico do desenvolvimento dos linfócitos B, onde a auto-reatividade parece ser utilizada em prol do desenvolvimento dessas células.

Palavras chave: Anticorpos, VH10, CDR H2 anti-DNA, Linfócitos B, Cadeia leve substituta (SLC), scFv, expressão heteróloga. 


\begin{abstract}
The anti-nucleic acids antibodies are important in the development of autoimmune diseases such as systemic lupus erythematosus (SLE). However, very little is known about the origin and maintenance of these antibodies by the body and interactions of these antibodies with their antigens. Studies in the literature and previous work of the Molecular Immunology team (UnB) show that the annotated sequences in database of the VH10 family that is part of the variable region of the heavy chain antibodies consisted mostly of sequences of anti-DNA molecules. Furthermore, through an experimental approach it was observed that this family has a certain independence from CDR H3 for this affinity. Based on these findings, we designed four antibody fragments in $\mathrm{scFv}$ format (single-chain fragment variable), this fragments preserves the antigen binding site that comprises a heavy chain $(\mathrm{VH})$ connected to a light chain, known surrogate light chain (SLC) in an attempt to simulate the antigen recognition in a specific moment in the development of B lymphocytes, where autoreactivity is used to promote the normal development of these cells. Also taking into account the independence of the $\mathrm{H} 3 \mathrm{CDR}$ for binding to antigen, we will also access through such constructions the role of CDR $\mathrm{H} 2$ for binding. After cloning the sequences into a plasmid for heterologous expression, these four scFvs were produced in Escherichia coli BL21 (DE3) pLysS. To date, after standardization of the conditions for soluble scFv production, conditions favorable for two of the four constructs were established. These constructions will enable the analysis of the role of the $\mathrm{V}$ gene segment, more specifically CDR2, for affinity to DNA antibodies originating from the germline segment VH10. In addition, you can simulate the antigen interaction of autoreactive and not autoreactive heavy chains at a specific time of the development of B lymphocytes, where self-reactivity seems to be used for the development of these cells.
\end{abstract}

Key words: Antibodies, VH10, CDR H2, anti-DNA, B lymphocytes, Surrogate light chain (SLC), scFv, heterologous expression. 



\section{INTRODUÇÃO}

Os anticorpos anti-ácidos nucleicos têm atraído ao longo dos anos o interesse dos pesquisadores principalmente pela sua presença acentuada em indivíduos com doenças autoimunes, porém ainda hoje as interações moleculares entre essas moléculas e seus ligantes, e as consequências dessas interações não são inteiramente compreendidas.

Anticorpos ligantes ao DNA já vêm sendo estudado pelo grupo de pesquisa de Imunologia Molecular da Universidade de Brasília. O objetivo desses estudos é compreender os mecanismos moleculares que são responsáveis por essa ligação e contextualizar essa informação com a bibliografia existente no que diz respeito ao desenvolvimento de células B e o surgimento de autoimunidade causada pelas características dessa interação.

A literatura relata que a família de cadeia variável pesada de origem murina VH10 apresenta característica intrínseca de ligação a ácidos nucleicos (WHITCOMB et al., 1999). Essa característica foi também observada por nosso grupo de pesquisa, após levantamento em banco de dados de informações das famílias de VHs murinas, onde constatou-se que de fato as sequências anotadas de VH10 consistiam em sua maioria de moléculas ligantes a ácidos nucleicos, na direção contrária, a família VH4 não apresenta nenhuma sequência com afinidade a ácidos nucleicos descrita. Dessa forma, as famílias de cadeia pesada VH10 e VH4 se mostram como ferramentas importantes para a compreensão dos mecanismos de afinidade ao DNA (MARANHÃO, 2001).

Através de uma abordagem experimental, utilizando-se tanto a família VH10 quanto a VH4, moléculas de scFvs dessas famílias foram expressas como componente estrutural na superfície de fagos pela técnica de phage display, o que permitiu a seleção dessas moléculas pela afinidade a DNA fita simples (ssDNA). Pôde-se observar experimentalmente que a família VH10 de fato apresenta uma tendência natural de se ligar ao DNA, apresentando certa independência da CDR H3 para essa ligação, diferente do observado para as moléculas de VH4 (GUEDES, 2009; COSTA, 2012). No trabalho de Costa e colaboradores, a evidencia de preferência do VH10 de formar anticorpos anti-DNA foi indireta baseada na diversidade dos CDR H3 identificados em bibliotecas selecionadas.

Neste trabalho, temos o objetivo de produzir fragmentos de anticorpos recombinantes que irão permitir a análise de reconhecimento antigênico (DNA fita simples) em um momento específico do desenvolvimento dos linfócitos B. Além disso, também será possível avaliar o 
papel da CDR H2 para a ligação ao DNA. Serão construídos fragmentos de anticorpos das cadeias pesadas de VH10 e VH4, em um contexto similar ao encontrado em células B em desenvolvimento, no qual estas células expressam uma cadeia leve características desse estágio para a formação do pré-BCR (receptor de célula pré-B) que reconhece antígenos próprios.

\section{REFERENCIAL TEÓRICO}

\subsection{SISTEMA IMUNE}

O sistema imunológico dos vertebrados evoluiu de forma complexa para a defesa e manutenção da homeostase do organismo. Diversas células e outros componentes do sistema imune convergem para a função de reconhecer e inativar estruturas estranhas ao organismo, tal complexidade e diversidade, levou a divisão da imunidade dos vertebrados em inata e adaptativa (BOEHM, 2012).

A imunidade inata compõe a primeira frente de defesa, caracterizada por ser uma resposta generalizada, baseada em padrões de reconhecimento de amplo espectro, rápida e com um nível de especificidade menor que a adaptativa. É composta por células mielóides, como, neutrófilos, macrófagos eosinófilos, basófilos e células dendríticas. Essas células atuam de forma quase imediata para a inativação e/ou destruição de qualquer estrutura estranha que possa ser nociva ao organismo (AKIRA, UEMATSU e TAKEUCHI, 2006).

Já a imunidade adaptativa é caracterizada por ser uma resposta lenta, porém, mais específica. É composta por células linfoides geradas na medula óssea, como, linfócitos B e T. Os linfócitos T são maturados e diferenciados no timo, existem subpopulações de células T, as células CD4+ e CD8+ são as mais estudadas. As células CD4+, também chamadas de helper, atuam como mensageiro, enviando sinais para que as diversas células do sistema imune ajam contra determinado invasor ou células defeituosas. As células CD8+, conhecidas como citotóxicas, atuam diretamente na destruição de células, infectadas por vírus e células potencialmente cancerígenas (LUCKHEERAM et al., 2012)

Os linfócitos B são originados e maturados na medula óssea, essas células são as únicas que produzem anticorpos, estes se ligam a um determinado antígeno com alta especificidade, inativando-o e marcando o mesmo para destruição. $O$ anticorpo em um primeiro momento é exposto na superfície do linfócito B como um receptor de membrana (BCR). A interação anticorpo-antígeno gera uma cascata de sinalização que resulta na 
diferenciação celular dos linfócitos B em plasmócitos, células capazes de secretar anticorpos. Apesar da imunidade inata e adaptativa serem categorizados diferentemente, o que se observa é a cooperação celular entre esses sistemas com influência mútua (LEBIEN e TEDDER, 2008)

\subsection{ANTICORPOS E DIVERSIDADE}

Descobertos em 1890, os anticorpos ou imunoglobulinas, são proteínas em forma de Y. A estrutura básica é composta por duas cadeias leves, L, e duas cadeias pesadas, H. A porção amino-terminal da molécula, também chamada de Fab (fragment antigen-binding) é formado por um domínio constante e um domínio variável de cada cadeia e é responsável pela ligação ao antígeno, enquanto a porção carboxi-terminal (região constante) é reconhecida pelas células efetoras do sistema imune. A região variável de Fab apresenta três regiões hipervariáveis em cada cadeia (leves e pesadas) que são as principais responsáveis pela variabilidade dessas moléculas, conhecidas como regiões determinantes de complementariedade (CDRs) (Figura 1).

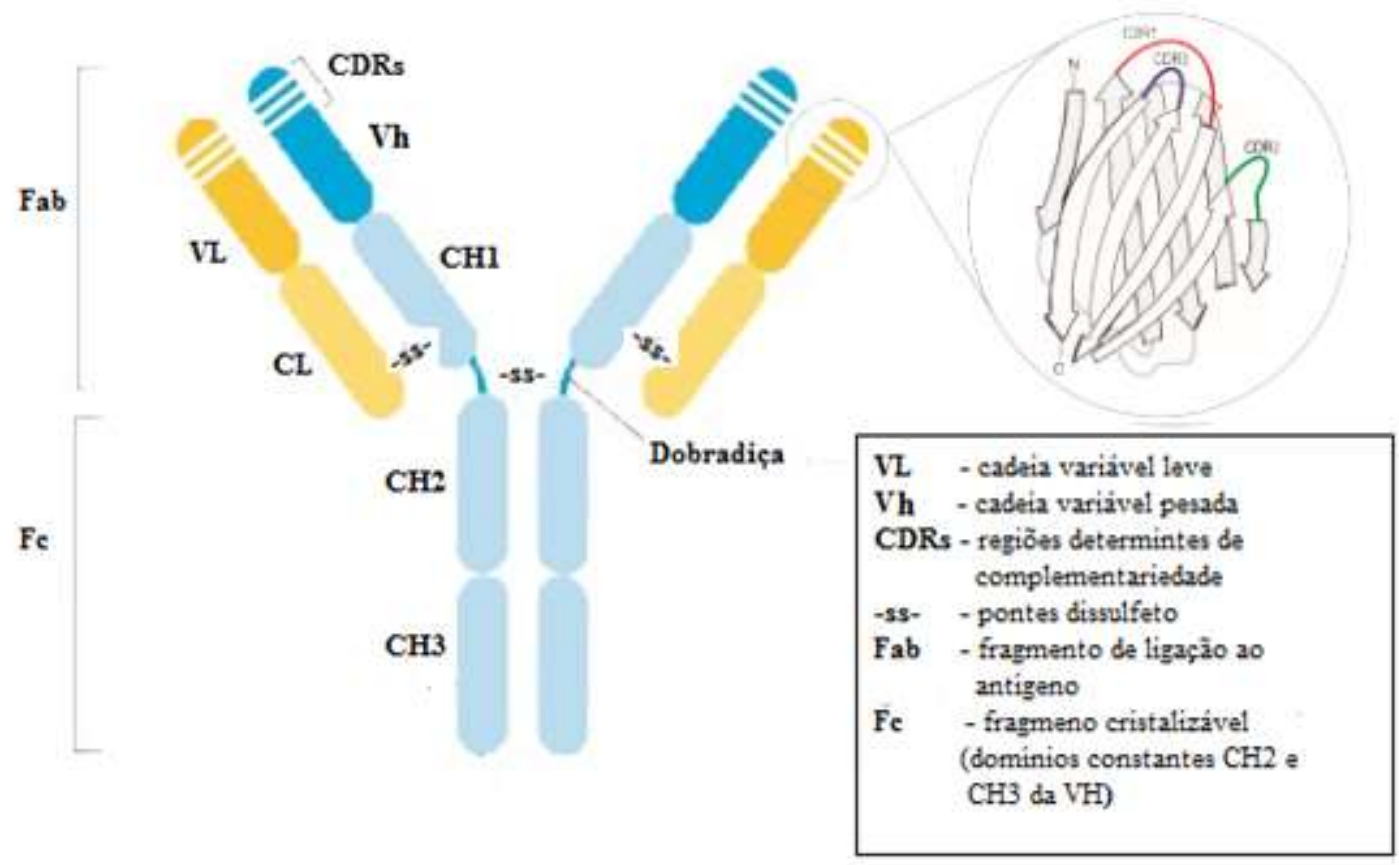

Figura 1. Desenho esquemático da estrutura de um anticorpo. (Adaptado de SIMI, 2014)

Os mecanismo de geração de variabilidade foi descrito primeiramente por Tonegawa em uma série experimentos entre os anos de 1970 e 1985, que lhe renderam o Prêmio Nobel de medicina e fisiologia em 1987 (TONEGAWA, 1988). Nestes experimentos foi 
demonstrado que os mecanismos de recombinação gênica dos segmentos gênicos VDJ permitem uma vasta combinação de fragmentos que darão origem a uma molécula única. Um humano pode produzir mais que $10^{12}$ moléculas de anticorpos diferentes, mesmo na ausência de antígenos, esse repertório primário pode ter reação cruzada com vários outros antígenos com diferentes afinidades, fazendo com que haja ao menos uma molécula ligante para qualquer antígeno que venha a existir. Além disso, um processo conhecido como maturação de afinidade pode aumentar a especificidade dessas moléculas após a estimulação antigênica (ALBERTS et al., 2002).

Hoje sabemos que cada tipo de cadeia de anticorpos tem conjuntos de segmentos gênicos separados. Uma variedade de segmentos que são unidos para a formação de uma cadeia única de anticorpo. A região $\mathrm{V}$ (variável), de uma imunoglobulina da cadeia leve ou pesada é codificada por mais de um segmento gênico. Dois desses segmentos formam a região $\mathrm{V}_{\mathrm{L}}$ das cadeias leves. $\mathrm{O}$ primeiro segmento forma a maior parte dessa região e é chamado de segmento $\mathrm{V}_{\mathrm{L}}$. $\mathrm{O}$ segundo segmento codifica o restante da cadeia ( 13 aminoácidos) sendo conhecido como $\mathrm{J}_{\mathrm{L}}$ (joining segment) (Figura 2). A junção desses dois segmentos forma um exon que codifica a região variável completa de uma cadeia leve (JUNG et al., 2006).

Diferentemente da cadeia leve formada por apenas 2 segmentos, a cadeia pesada é codificada por 3 segmentos gênicos. Os segmentos $V_{H}$ e $J_{H}$ e um terceiro segmento conhecido como diversity ou segmento $\mathrm{D}_{\mathrm{H}}$ que fica entre os segmentos $\mathrm{V}_{\mathrm{H}}$ e $\mathrm{J}_{\mathrm{H}}$. Primeiramente o segmento $D_{H}$ é unido ao segmento $J_{H}$ formando $D_{H}$, e em seguida o segmento $V_{H}$ é também unido ao segmento $\mathrm{DJ}_{\mathrm{H}}$ (Figura 2) formando a região variável completa de uma cadeia pesada (AFSHAR et al., 2013).
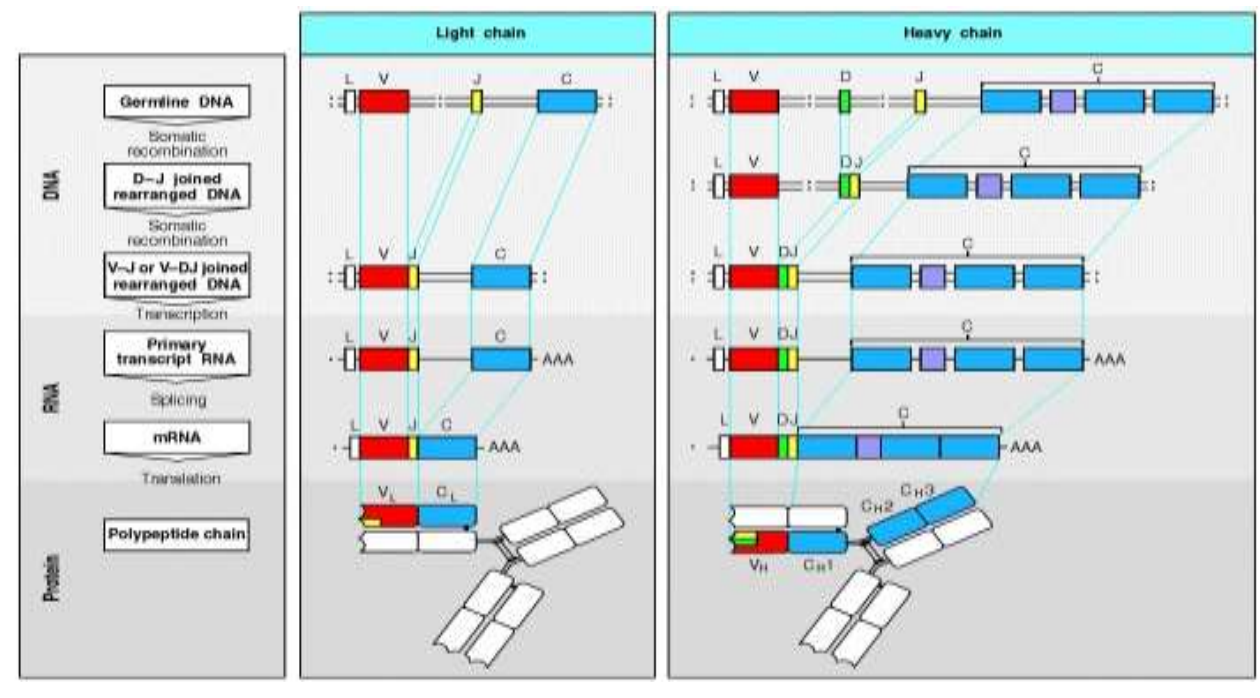
Figura 2. Representação esquemática da formação das cadeias leve e pesadas das imunoglobulinas pela união dos segmentos gênicos V e J (cadeia leve) e V, D e J (cadeia pesada). (Fonte: Janeway, 2005)

O locus murino dos segmentos $\mathrm{V}_{\mathrm{H}}$ de cadeia pesada, está localizado no cromossomo 12 e consiste de uma região de $3.1 \mathrm{Mb}$, onde cerca de 141 segmentos, dos quais 104 funcionais, podem ser encontrados, estes são divididos em 15 famílias (subgrupos). O segmento $V_{H}$ contém em sua sequência regiões para a formação das CDR H1 e H2. A CDR $\mathrm{H} 3$ é formada pelo segmento $\mathrm{V}_{\mathrm{H}}, \mathrm{D}_{\mathrm{H}}$ e o início do segmento $\mathrm{J}_{\mathrm{H}}$ (DE BONO, MADERA e CHOTHIA, 2004).

As cadeias leve e pesada apresentam três CDRs cada, a mais variável é a CDR3 da cadeia pesada, pois é formada por mais fragmentos gênicos durante a recombinação, além disso, outros mecanismos envolvidos na ligação desses fragmentos inserem nucleotídeos de forma aleatória, conhecidos como adição de nucleotídeos $\mathrm{N}$, mais comuns em junções da cadeia pesada, e adição de nucleotídeos P. Essa maior variabilidade confere a CDR H3 uma maior relevância quando se investiga a ligação antigênica do anticorpo (JACKSON et al., 2004; REPASKY et al., 2004).

Apesar da bem estabelecida importância da CDR H3 para a ligação antigênica, as CDR1 e CDR2 são também necessárias para a definição dessa ligação. Além, disso as regiões fora das CDRs (frameworks) também desempenham papel na conformação da molécula para que os sítios de ligação localizados nas CDRs fiquem expostos de modo a favorecer a afinidade dessa molécula ao antígeno. Foi reportado que em torno de $20 \%$ dos aminoácidos de anticorpos que interagem com o antígeno podem se encontrar fora das CDRs, e que estes, são tão importantes para a ligação ao antígeno quanto os que se localizam dentro das CDRs (KUNIK, PETERS e OFRAN, 2012)

\subsection{DESENVOLVIMENTO DOS LINFÓCITOS B}

Os linfócitos B são originadas de células tronco hematopoiéticas localizadas na medula óssea, durante esse processo há uma intensa e coordenada cascata de sinalização molecular externas e internas as células progenitoras que guiam o processo de diferenciação celular, a partir de uma célula multipotente. Esse processo de sinalização é marcado por checkpoints que vão definindo passo a passo o destino da célula até a maturação linfócitos (LEBIEN e TEDDER, 2008). 
O ambiente da medula óssea fornece os sinais necessários para a diferenciação das células B. Os sinais externos são produzidos pelas células estromais que interagem intimamente com os linfócitos em desenvolvimento, fornecendo citocinas que controlam a diferenciação e proliferação dessas células. A citocina IL-7 secretada pelas células estromais, por exemplo, é fundamental para o crescimento e a sobrevivência dos linfócitos B em camundongos (HARA et al., 2012; WEI, ZEFF e GOLDSCHNEIDER, 2000).

Os estágios do desenvolvimento podem ser identificados e caracterizados pelos marcadores de superfície dessas células (Figura 3). Os principais estágios do desenvolvimento são tratados a seguir.

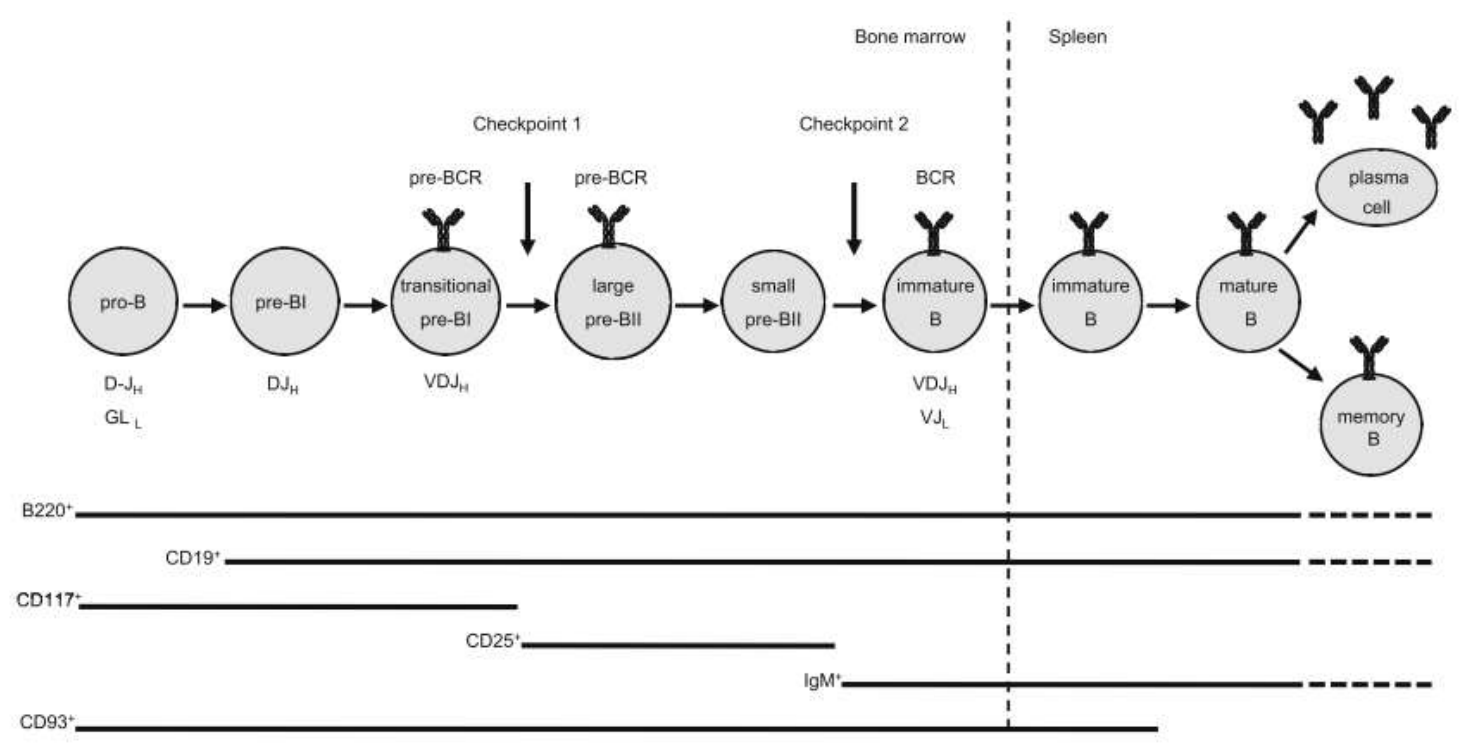

Figura 3. Etapas do desenvolvimento dos linfócitos B. (Adaptada de Mårtensson et al. 2010)

A primeira etapa de diferenciação ocorre quando a célula se encontra no estágio pró-B no qual ocorre a recombinação dos segmentos gênicos D-J da cadeia pesada e a expressão característica dos marcadores de superfície B220 ${ }^{+}, \mathrm{CD} 117^{+}$e CD93 ${ }^{+}$. Posteriormente, na fase pré-B as células B apresentação a junção do segmento $\mathrm{V}$ aos segmentos D-J já recombinados, obtendo-se dessa forma o segmento VDJ completo, possibilitando a expressão da nova cadeia pesada $(\mu \mathrm{H})$. Nessa fase também se inicia a expressão do pré-BCR (receptor das células préB), onde ocorre o pareamento da cadeia pesada $(\mu \mathrm{H})$ com cadeia leve substituta (SLC). É nessa etapa também que as células são estimuladas através do pré-BCR possivelmente por antígenos próprios selecionando negativamente as células que não atenderem aos requisitos desta sinalização, enquanto as células com sinalização satisfatória são induzidas a proliferar. Após a seleção exercida pela sinalização do pré-BCR, sua expressão é reduzida e as células cessam a proliferação entrando no estágio pré-BII. O próprio pré-BCR regula negativamente a 
expressão dos genes codificadores dos componentes que formam a SLC, VpreB e $\lambda 5$, reduzindo a expressão da SLC (PARKER et al., 2005).

No final da fase pré-BII o pré-BCR deixa de ser expresso na superfície celular e a expressão da SLC não é mais detectada. Nesse momento, os genes RAG (recombinationactivating gene) são expressos novamente e a cadeia leve convencional (LC) sofre recombinação, e então passa a ser expressa junto com a cadeia pesada $(\mu \mathrm{H})$, posicionando na superfície celular o receptor de células B, o BCR. Este receptor é expresso na forma de um anticorpo $\operatorname{IgM}$ e posteriormente co-expresso com a forma $\operatorname{IgD}$, que não é secretado neste momento, permanecendo ligado à membrana celular. A partir daí as células são consideras células B imaturas, que deixam a medula óssea e migram para o baço onde completaram o ciclo de desenvolvimento, podendo se tornarem células de memória ou plasmócitos após o reconhecimento de um antígeno (MÅRTENSSON et al., 2010).

\subsection{PRÉ-BCR}

O pré-BCR diferentemente do BCR expresso em células B desenvolvidas, é formado por uma cadeia pesada e uma cadeia leve não convencional, conhecida como surrogate light chain (SLC). A SLC invariante é formada por dois polipeptídios VpreB e $\lambda 5$, ligados de forma não-covalente, a porção $\lambda 5$ se liga covalentemente a cadeia pesada de forma similar a ligação observada com a cadeia leve convencional (BANKOVICH et al., 2007). Também apresentam regiões únicas (tails) que podem ser importantes para a sinalização, através de contato direto com as células estromais da medula (BRADL et al., 2003).

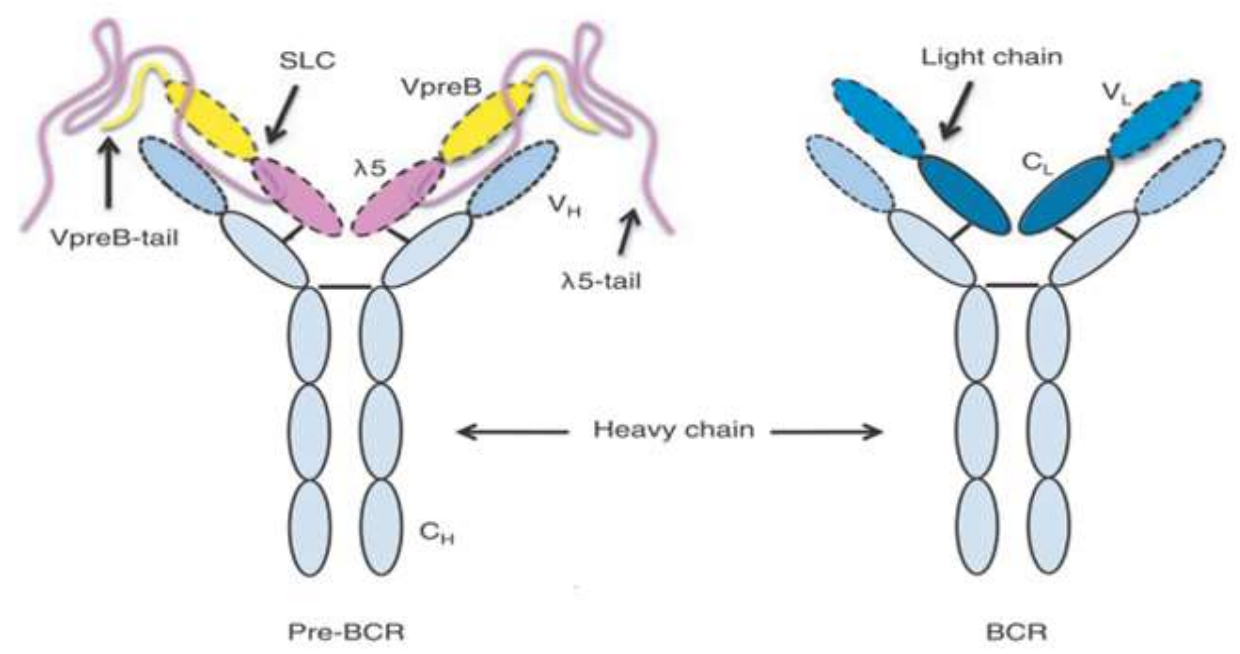

Figura 4. Comparação esquemática do pré-BCR com o BCR. (Adaptado de Almqvist e Mårtensson, 2012). 
O pré-BCR é expresso na superfície celular na fase pré-B do desenvolvimento e em níveis menores quando comparado com o $\mathrm{BCR}$. Células que não expressam ou não conseguem o pareamento satisfatório da SLC com a VH são incapazes de proliferar corretamente e progredir para os próximos estágios do desenvolvimento. A importância da SLC para o desenvolvimento das células B foi observada em camundongos deficientes para algum dos dois componentes formadores desta cadeia (VpreB e $\lambda 5$ ) ou alguma molécula dessa via de sinalização. As células B desses animais apresentam defeitos na expressão de marcadores de maturação, no rearranjo da cadeia leve e uma capacidade de proliferação aumentada quando estimulada por IL-7 (SHIMIZU et al., 2002). Em outro estudo, foi observado que camundongos com genótipo $\mathrm{SLC}^{\top}$ - produziram anticorpos anti-DNA e antinucleares (ANAs), onde também foi observado o aumento da presença de aminoácidos de carga positiva nas CDRs H3 dos anticorpos desses camundongos depois do checkpoint, o que não foi observado no controle $\left(\mathrm{SLC}^{+} \digamma^{+}\right)$. Apesar do fenótipo apresentado, os camundongos SLC ${ }^{\top}{ }^{-}$não apresentaram sintomas de nenhuma doença autoimune (KEENAN et al., 2008).

Também foi observado que a expressão a expressão ectópica de VpreB e $\lambda 5$ de células B maduras (fora do contexto de desenvolvimento celular) de camundongos transgênicos promoveu uma leve ativação dos linfócitos B, porém nenhum sinal de autoimunidade foi detectado, e que curiosamente a expressão prolongada de VpreB protegeu o animal de artrite induzida pela indução dose-dependente de deleção clonal e anergia (KIL et al., 2015).

Em humanos, apenas um paciente foi estudado. O indivíduo apresentava mutações nos dois genes formadores da SLC ( $\lambda 5$ e 14.1), resultando em severo bloqueio do desenvolvimento de linfócitos B, e consequentemente uma contagem baixa de linfócitos $\mathrm{B}$ circulantes, além disso, foi observado a ausência de anticorpos contra doenças para as quais o paciente tinha sido vacinado, indicando possível ausência de células B de memória (MINEGISHI et al., 1998).

\subsection{INTERAÇÃO ANTICORPO-ANTÍGENO}

Os anticorpos são moléculas especializadas na ligação ao antígeno. Como citado anteriormente, mecanismos que permitem a recombinação dos genes responsáveis pela formação dos domínios variáveis dos anticorpos permitem uma variabilidade imensa de ligantes, sendo virtualmente plausível encontrar anticorpos ligantes para todos os antígenos existentes. A alta afinidade e especificidade desses anticorpos pelos antígenos que após a 
ligação irão ser inativados e/ou marcados para destruição são cruciais para o desenvolvimento da resposta imune mediada pelos linfócitos B.

As interações anticorpo-antígeno são feitas por ligações não-covalentes e as principais regiões do anticorpo que entram em contato direto com o antígeno são as CDRs. Estas regiões são de grande importância para a ligação ao antígeno, porém regiões críticas para a afinidade podem residir fora das sequências das CDRs (KUNIK, PETERS e OFRAN, 2012). Os frameworks também fazem parte da porção variável, porém são regiões mais conservadas e são responsáveis pela formação estrutural da região variável do Fab, sendo importante para o correto dobramento da molécula naquela região, expondo as CDRs para o meio externo. As CDRs formam uma estrutura em loops características, que irão entrar em contato direto com antígeno (HSU et al., 2014).

A figura 5 apressenta uma representação deduzida por ressonância magnética nuclear (NMR) do complexo de ligação de um fragmento de anticorpo que preserva apenas os domínios de ligação ao antígeno ( $\mathrm{scFv}$ ) onde é possível observar a formação dos loops característicos, formados por resíduos conservados dentro das CDRs. Também é possível perceber o contato direto de praticamente todas as CDRs com o antígeno IL-1 $\beta$ (interleucina $1 \beta$ ) representado em cinza (NORTH, LEHMANN e JR, 2012; WILKINSON et al., 2009).

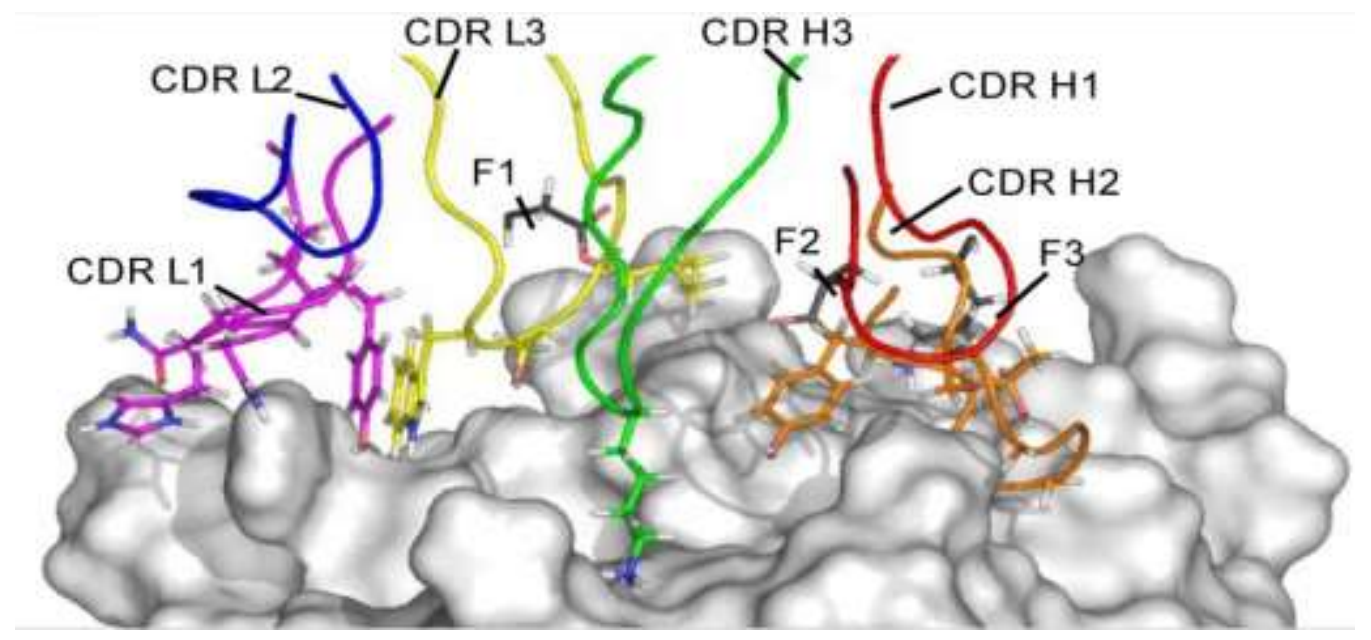

Figura 5. Representação da ligação estabelecida entre as regiões de um scFv (colorido) e seu antígeno alvo (cinza) (Adaptada de Wilkinson et al., 2009).

Ainda que a CDR H3 seja conhecidamente a região mais variável e por isso mais importante para a ligação ao antígeno, não necessariamente determina por si só a ocorrência ou não da ligação ao antígeno. Uma biblioteca de sequências com variabilidade similar foi criada para a CDR H3 e CDR L3 na construção de moléculas recombinantes, tal incremento 
de variabilidade não natural na CDR L3 levou a seleção de sequências variadas dessa cadeia, enquanto pouco enriquecimento foi observado para a CDR H3, apresentando sequências inertes para a ligação (PERSSON et al., 2013). Tal fato indica a possibilidade de que na ausência da CDR H3 com potencial de ligação para determinado antígeno, outras CDRs podem assumir o papel de principal ligante.

\subsection{ANTICORPOS ANTI-DNA}

Existem anticorpos que reconhecem não apenas estruturas de origem externa ao organismo, mas também estruturas próprias. Essa característica de reconhecimento do próprio tem sido apontada como a provável causa inicial para o desenvolvimento de doenças autoimunes. Anticorpos auto-reativos são característicos de algumas doenças autoimunes, o exemplo clássico é o lúpus eritematoso sistêmico (LES), condição patológica na qual o corpo ataca seus próprios tecidos saudáveis, podendo afetar a pele, juntas, rins, cérebro e outros órgãos (ARBUCKLE et al., 2001).

Anticorpos anti-DNA são comumente encontrado no soro desses pacientes em algum estágio da doença, servindo como indicação para diagnóstico e monitoramento do quadro patológico. Ainda não está claro o papel danoso desses anticorpos no LES, o fato é que eles estão presentes em cerca de $70 \%$ dos indivíduos doentes em algum estágio, principalmente nos tecidos afetados (ISENBERG et al., 2007). Porém, anticorpos anti-DNA são também encontrados no soro de pacientes saudáveis, e é aqui onde a questão se complica. Será que esses anticorpos encontrado em pacientes com LES têm realmente algum papel crítico para o estabelecimento da doença? Se sim, por que indivíduos saudáveis não apresentam sintomas da doença? Claro que nós sabemos que uma série de fatores de regulação têm que falhar para o estabelecimento de uma condição autoimune, porém essas são questões fundamentais para se entender a origem e manutenção desses anticorpos pelo organismo.

Algumas evidências indicam que células B que expressam anticorpos auto-reativos tendem a serem selecionadas negativamente durante o desenvolvimento. O que pode soar estranho já que esses anticorpos podem ser encontrados em indivíduos saudáveis, porém em um nível menor. De fato, alguns anticorpos auto-reativos, já foram descritos como agentes que auxiliam na manutenção da homeostase do organismo, por exemplo, na remoção de células apóptóticas prevenindo os efeitos adversos do acúmulo desse material que pode ativar a resposta imune adaptativa resultando em uma condição autoimune (BOES et al., 2000). O panorama que se desenha no que diz respeito a anticorpos auto-reativos, é que estes não são 
apenas produtos de mau funcionamento do sistema, mas são úteis para o funcionamento normal do organismo, e que mecanismos de controle e tolerância mantêm células potencialmente auto-reativas sob vigilância.

\subsubsection{Características dos anticorpos anti-DNA}

Anticorpos anti-DNA são usados como modelo para o estudo dessas interações. As análises entre essas moléculas e o objeto de estudo são importantes para a identificação de um padrão, um fingerprint que permita a identificação rápida desses anticorpos. Na prática, essa característica é diversificada, tornando essa uma tarefa não tão simples. De fato, existem traços característicos de anticorpos anti-DNA, como a presença acentuada de aminoácidos positivamente carregados nas CDRs, principalmente arginina (R), mas a ausência desse padrão não anula a possibilidade da auto-reatividade (SONG et al., 2008).

O anticorpo BV04-01 é um modelo para o estudo de anticorpos anti-DNA, essa molécula é um fragmento Fab derivado de auto-anticorpos de camundongos modelo para LES. A cristalização desse peptídeo foi alcançada enquanto ligado a um trinucleotídeo de timinas, o que permitiu a observação da interação e modificações conformacionais que permitiram a ligação entre essas duas moléculas. As regiões da CDR3 das cadeias leves e pesadas passaram por pequenos ajustes conformacionais durante a formação do complexo, o que fez com que a estrutura de fosfato e açúcar do trinucleotídeo adotasse uma conformação estendida, expondo os sítios para a interação com a proteína. O primeiro nucleotídeo estava ligado somente a cadeia pesada $(\mathrm{VH})$ através de pontes de hidrogênio com resíduos de serina (S) e asparagina $(\mathrm{N})$, o segundo nucleotídeo estava interagindo com as duas cadeias, através de ligação iônica com um resíduo de arginina (R) da cadeia pesada e o terceiro nucleotídeo estava ligado apenas a cadeia leve (VL), o sítio de maior interação estava localizado no segundo nucleotídeo, onde a densidade estrutural permitiu a compactação e formação de pontes de hidrogênio (HERRON et al., 1991).

A cristalização de outro complexo com um fragmento de anticorpo ligante a oligo (dT), Fab-dT 5 , mostrou que apesar destes anticorpos possuírem os mesmos ligantes, as ligações podem se estabelecer de formas diferentes no que diz respeito as regiões de maior relevância para a formação do complexo. Observou-se que a CDR H3 na formação do complexo BV04-01- $\mathrm{dT}_{3}$ desempenha um papel importante interagindo com dois nucleotídeos, formando uma estrutura essencial para a afinidade. Já na formação do complexo Fab1-dT 5 , a CDR H3 interage com 4 nucleotídeos, porém essa interação é fraca. A CDR L2 não é 
utilizada para a formação do complexo BV04-01-dT 3 , porém é essencial para a formação do complexo Fab1-dT 5 , entre outras diferenças (TANNER, KOMISSAROV e DEUTSCHER, 2001).

\subsection{FRAGMENTOS DE ANTICORPOS, scFv}

Com o advento da tecnologia do DNA recombinante a manipulação e engenharia de moléculas se tornou possível. No campo da imunologia, vários anticorpos, na forma de seus fragmentos, passaram a ser construídos, visando-se um melhor desempenho da molécula para determinada finalidade, seja para a utilização na pesquisa, diagnóstico ou terapêutica (KONTERMANN, 2010)

Dentre estes fragmentos de anticorpos, os scFvs (single-chain fragment variable) são moléculas formadas apenas pela região variável do anticorpo, uma porção variável da cadeia pesada é ligada por linker peptídico de 15 aminoácidos (GGGGS x3) a uma porção variável da cadeia leve (Figura 6). A presença apenas da região variável dos anticorpos, permite que a mesma função exercida por esse domínio na molécula inteira, seja também desempenhada pelo scFv, que é a ligação ao antígeno (NELSON, 2010).
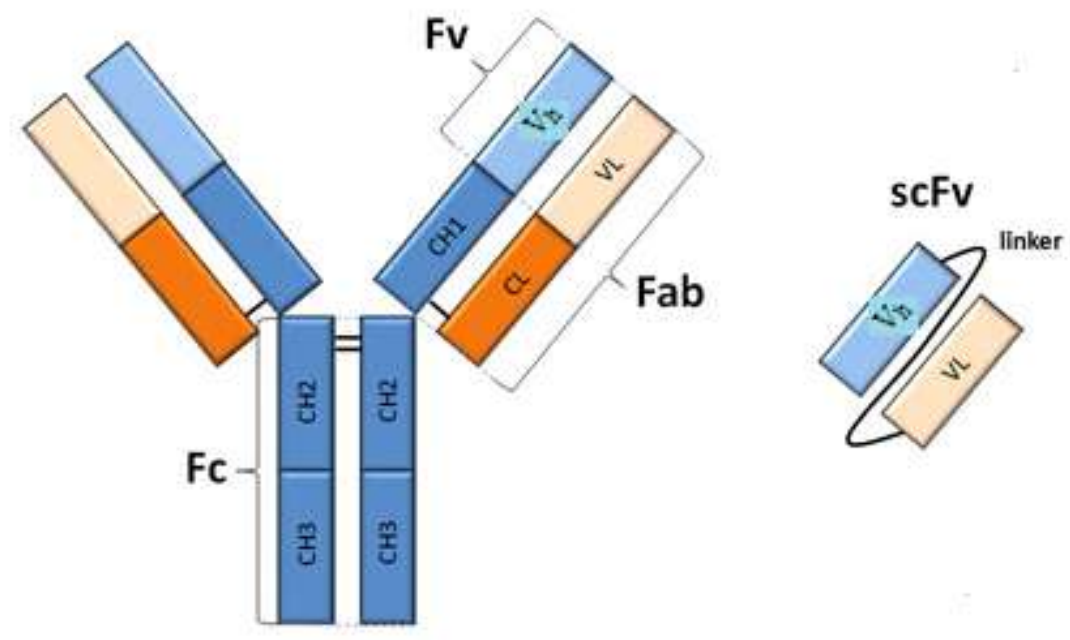

Figura 6. Desenho esquemático de anticorpo inteiro (esquerda) e um fragmento scFv (direita).

Essas moléculas foram idealizadas tanto para a aplicação clínica, por apresentarem características vantajosas, a penetrabilidade tecidual dessas moléculas é uma delas. Porém essas moléculas podem também ser utilizadas na pesquisa, alta especificidade e tamanho também são aproveitadas nessa área. Os scFvs são moléculas pequenas, cerca de $30 \mathrm{kDa}$, 
ideais para sistemas de expressão bacteriano, no qual é possível expressar moléculas simples com qualidade e em grandes quantidades (AHMAD et al., 2012).

\subsection{EXPRESSÃO DE PEPTÍDEOS EM CÉLULAS BACTERIANAS}

Sistemas de expressão bacterianos são amplamente utilizados, sendo cepas de Escherichia coli a mais utilizada. O sistema de expressão já bem estabelecido favorece a escolha desses organismos que em se tratando de proteínas de pouca complexidade desempenham com êxito essa função. Vários aspectos são levados em consideração nesses sistemas como, a estrita regulação dos promotores procarióticos que permitem uma alta expressão gênica, o codon usage ideal, bem como as diferentes linhagens variantes que permitem a escolha do melhor sistema disponível para a expressão heteróloga, contribuindo para sua estabilidade, integridade e atividade biológica (BILGIMOL et al., 2015).

Muitos sistemas de expressão bacteriana, como o pET, apresentam um sistema de expressão baseado no gene 10 do fago T7. O gene de interesse é regulado pelo promotor T7 de fagos, considerado um promotor forte, este permite produção de proteínas em grandes quantidades, a expressão é induzida fornecendo-se uma fonte de RNA polimerase T7. Cepas modificadas para a expressão heteróloga apresentam no seu genoma o gene para codificar a RNA polimerase T7 derivada de fagos, essa polimerase está sob o controle do promotor lac, tendo sua expressão induzida na presença de IPTG. A polimerase viral se faz necessária pelo fato do promotor T7 no plasmídeo ser específico, a RNA polimerase constitutiva da cepa bacteriana não se liga ao promotor viral. A ativação faz com que grande parte do metabolismo celular seja deslocado para a expressão gênica, em poucas horas a quantidade da proteína de interesse pode representar mais de 50\% do total de proteína na célula (TERPE, 2006).

Seria esperado haver pouca ou nenhuma expressão na ausência de um indutor e que a expressão se iniciaria no momento em que o indutor fosse adicionado, porém nem sempre isso ocorre, outros fatores que não somente a presença do indutor estão envolvidos na eficiência da expressão. O AMP cíclico e seu receptor (CAP), por exemplo, também são necessários para a expressão, o complexo CAP/cAMP se liga próximo ao promotor e estimula a expressão da RNA polimerase T7. Os níveis de cAMP nas células é dependente da fonte de carbono utilizada, na presença de glicose os níveis cAMP caem, dimuindo a formação do complexo que ativaria a expressão da RNA polimerase T7, dessa forma a transcrição do gene de interesse também será baixa. Na ausência de glicose, a célula utilizará outras fontes de 
carbono, subindo os níveis de cAMP, permitindo a formação do complexo, que resultará na eficiente produção da proteína de interesse (NOVY e MORRIS, 2001).

Os controles dos mecanismos de expressão são fundamentais para a produção eficiente da proteína. Algumas cepas, possuem o plasmídeo pLysS, que expressa a lisozima T7, uma inibidora da T7 RNA polimerase. As utilizações desses mecanismos adicionais de controle da expressão são dependentes do impacto da produção da proteína heteróloga na célula bacteriana, visando-se uma maior eficiência na produção principalmente de produtos tóxicos para as células (ZHANG e STUDIER, 1997).

\subsection{HIPÓTESES}

A presença de sequências germinais das famílias de cadeia pesada, principalmente VH10, descritas como ligantes a ácidos nucleicos é um fato que merece atenção, uma vez que mais da metade das sequências anotadas de VH10 foram descritas com essa característica (Tabela 1). A presença de uma afinidade intrínseca dessa família para com o DNA pode estar relacionada com o processo de desenvolvimento dos linfócitos $\mathrm{B}$, uma vez que essas células necessitam de estímulos, provavelmente mediados por antígenos próprios (como o DNA) ainda na medula óssea, e consequentemente no estabelecimento do repertório primário de células B maduras potencialmente auto-reativas. Na tentativa de demonstrar indiretamente essas possibilidades, nós pretendemos simular a possível interação de um pré-BCR composto de uma VH com sequência germinal de VH10 ou VH4 (controle) e da cadeia leve substituta (SLC), expressa somente em células no estágio pré-B do desenvolvimento.

Além disso, a afinidade a ácidos nucleicos observada para membros da família VH10 sugere que elementos do fragmento gênico $V$ contribuem significativamente para a especificidade pelo DNA. Testamos essa hipótese selecionando peptídeos de CDR H3 por phage display para afinidade a DNA fita simples (ssDNA). Os fagos selecionados foram sequenciados em alto desempenho o que permitiu a análise de um grande número de sequências. Utilizando uma abordagem entrópica, mostrou-se que um fragmento gênico $\mathrm{V}$ da família VH10 apresenta uma certa independência do segmento CDR H3 para a ligação ao ssDNA, diferentemente do observado para $\mathrm{VH} 4$, que se mostrou mais restritivo no aspecto de diversidade de CDR H3 compatíveis. (COSTA, 2012).

Tal análise nos levou a questionar se o CDR H3 no contexto VH10 é de fato o principal fator para a ligação antigênica, quando as evidências apontam para regiões fora da CDR H3. Provavelmente elementos do fragmento gênico V contribuem de forma efetiva para 
a afinidade pelo DNA. Nesse trabalho iremos além, perguntando que se temos reatividade dependente de do segmento gênico V gene, e se podemos eliminá-la, modificando elementos estruturais como a CDR H2. 
Tabela 1: Análise das sequências de segmentos gênicos VH murinos depositados no banco de dados Genbank anotados quanto a especificidade (Adaptado de COSTA, 2012).

\begin{tabular}{|c|c|c|c|c|c|c|c|c|}
\hline Família & $\begin{array}{l}\text { Seqüûencias } \\
\text { depositadas }{ }^{1}\end{array}$ & $\begin{array}{c}\text { Freqüência de } \\
\text { seqüuências } \\
\text { das famílias }{ }^{2}\end{array}$ & $\begin{array}{l}\text { Média do } \\
\text { número de } \\
\text { germinais }^{3}\end{array}$ & $\begin{array}{c}\text { Freqüência } \\
\text { das famílias/ } \\
n^{\circ} \text { de } \\
\text { germinais }\end{array}$ & $\begin{array}{c}\text { Freqüência } \\
\text { de germi- } \\
\text { nais }^{4}(\%)\end{array}$ & $\begin{array}{c}\text { Número de } \\
\text { seqüiências } \\
\text { ligantes a ácidos } \\
\text { nucléicos }^{5}\end{array}$ & $\begin{array}{c}\text { Freqüência de } \\
\text { seqüuências } \\
\text { ligantes em cada } \\
\text { família }^{6}(\%)\end{array}$ & $\begin{array}{l}\text { Freqüência } \\
\text { de ligantes/ } \\
\text { seqüência } \\
\text { de germinais }\end{array}$ \\
\hline VH1 & 2348 & 66,6 & 100,0 & 0,7 & 56,7 & 422 & 18,0 & 0,2 \\
\hline VH2 & 237 & 6,7 & 15,0 & 0,4 & 8,5 & 96 & 40,5 & 2,7 \\
\hline VH3 & 148 & 4,2 & 6,5 & 0,6 & 3,7 & 19 & 12,8 & 2,0 \\
\hline VH4 & 32 & 0,9 & 2,0 & 0,5 & 1,1 & 0 & 0,0 & 0,0 \\
\hline VH5 & 327 & 9,3 & 12,0 & 0,8 & 6,8 & 120 & 36,7 & 3,1 \\
\hline VH6 & 101 & 2,9 & 11,0 & 0,3 & 6,2 & 14 & 13,9 & 1,3 \\
\hline VH7 & 170 & 4,8 & 3,0 & 1,6 & 1,7 & 45 & 26,5 & 8,8 \\
\hline VH8 & 44 & 1,2 & 8,5 & 0,1 & 4,8 & 5 & 11,4 & 1,3 \\
\hline VH9 & 66 & 1,9 & 6,0 & 0,3 & 3,4 & 6 & 9,1 & 1,5 \\
\hline VH10 & 37 & 1,0 & 3,5 & 0,3 & 2,0 & 22 & 59,5 & 17,0 \\
\hline VH11 & 9 & 0,3 & 3,5 & 0,1 & 2,0 & 0 & 0,0 & 0,0 \\
\hline VH12 & 1 & 0,0 & 1,0 & 0,0 & 0,6 & 0 & 0,0 & 0,0 \\
\hline VH13 & 1 & 0,0 & 1,0 & 0,0 & 0,6 & 0 & 0,0 & 0,0 \\
\hline VH14 & 4 & 0,1 & 3,5 & 0,0 & 2,0 & 0 & 0,0 & 0,0 \\
\hline Total & 3525 & 100,0 & 176,5 & - & 100,0 & 749 & - & - \\
\hline
\end{tabular}

${ }^{1}$ Número de sequências depositadas em bancos de dados contendo CDR H3 de cada família

${ }^{2}$ Percentual de sequências de cada família na amostra analisada

${ }^{3}$ Média do número estimado de segmentos germinais levando em conta as diferentes linhagens de camundongos

${ }^{4}$ Número de segmentos germinais de cada família dividida pelo repertório total de $\mathrm{VH}$

${ }^{5}$ Número de sequências descritas como ligantes a ácidos nucléicos

${ }^{6}$ Número de sequências ligantes a ácidos nucléicos dividido pelo número total de sequências de cada família 


\section{ABORDAGEM EXPERIMENTAL}

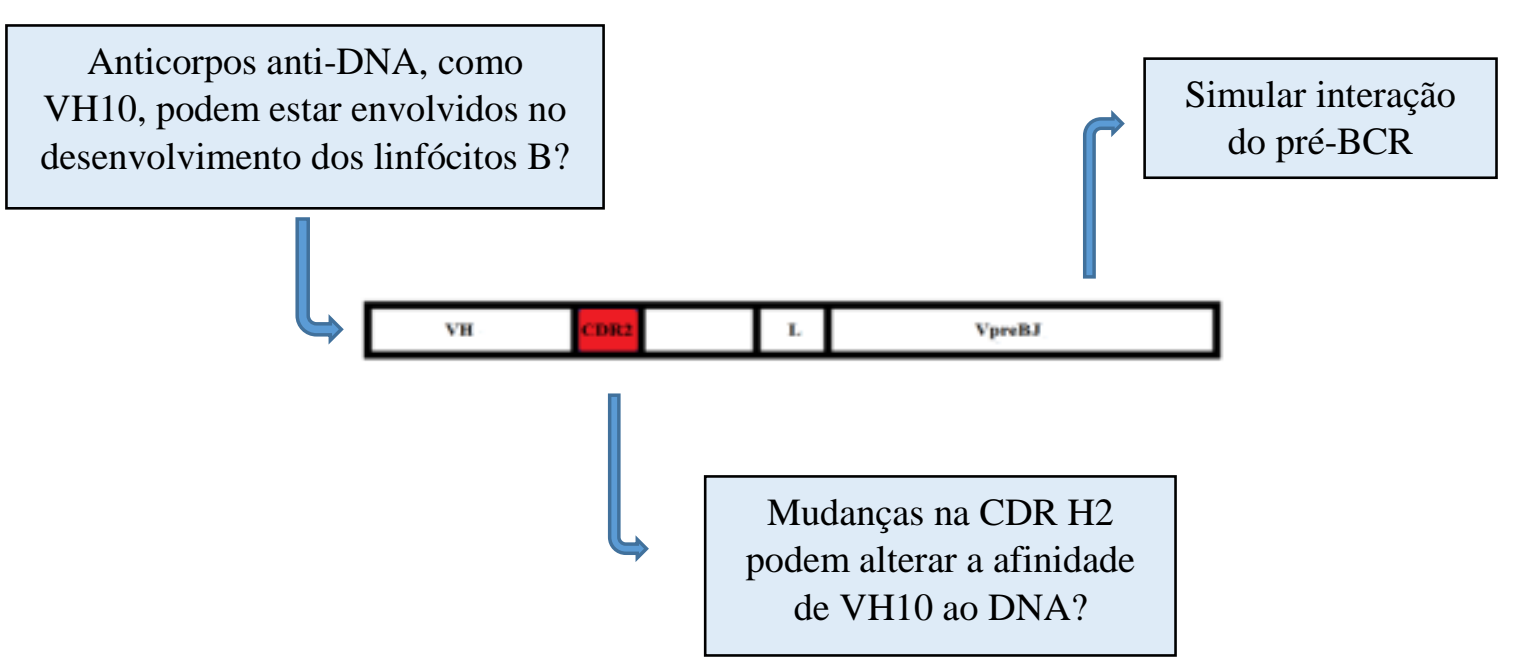

Figura 7. Modelo generalizado do scFvs produzidos.

Na tentativa de responder algumas de nossas hipóteses, nós construímos 4 moléculas no formato scFv. Sendo dois desses polipeptídeos formados pela sequência germinal de VH da família 4 ou 10, acompanhados pela cadeia leve substituta (SLC) (Figura 7), e os outros dois scFvs nos quais as duas moléculas originais apresentavam a CDR2 trocadas entre si. As sequências gênicas foram clonadas em vetor de expressão bacteriana para a produção dessas moléculas as quais serão testadas com relação a afinidade a ssDNA (single stranded $D N A$ ). $\mathrm{Na}$ figura 8 é apresentado o esquematicamente os passos da abordagem experimental.

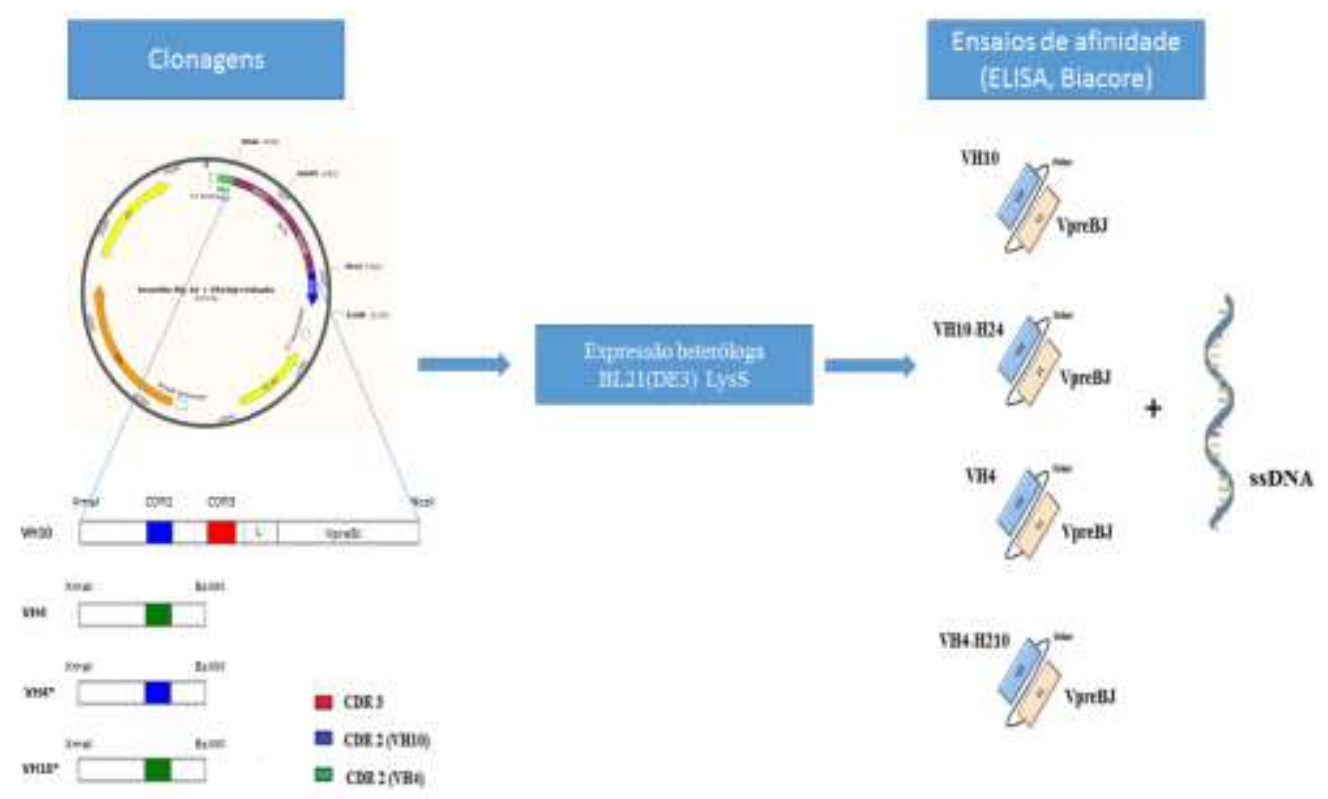

Figura 8. Representação esquemática da abordagem experimental 


\section{OBJETIVOS}

\subsection{OBJETIVO GERAL}

- Produzir e testar a afinidade de scFvs em um contexto VpreBJ com ênfase nas diferenças da CDR H2 da cadeia variável pesada de sequências germinais das famílias VH10 e VH4.

\subsection{OBJETIVOS ESPECÍFICOS}

- Construir quatro sequências recombinates de scFvs no contexto VpreBJ com sequências germinais das famílias VH10 e VH4.

- Clonar as sequências desenhadas no vetor pig16 para a produção de fragmentos de anticorpos recombinantes.

- Identificar as condições ideais para a expressão de proteínas solúveis.

- Produzir as proteínas recombinantes através da expressão heteróloga em bactérias. 


\section{MATERIAL E MÉTODOS}

\subsection{MATERIAL}

\subsubsection{Linhagens bacterianas}

XL1-Blue (Stratagene $\left.{ }^{\circledR}\right)$ (amplificação e clonagens) $\rightarrow$ recA1 endA1 gyrA96 thi-1 hsdR17 supE44 relA1 lac [F proAB lacIqZ M15Tn10 (TetR )] (Sambrook et al., 1989)

BL21 (DE3) pLysS (expressão heteróloga) $\rightarrow$ F-, ompT, hsdSB $\square$ (rB-, mB-), dcm, gal (DE3), pLysS, $\mathrm{Cm}^{\mathrm{r}}$

\subsubsection{Meios de cultura e soluções afins}

\section{Meio LB (Luria-Bertani)}

Peptona de caseína $1 \%(\mathrm{p} / \mathrm{v})$

Extrato de levedura $\quad 0,5 \%(\mathrm{p} / \mathrm{v})$

$\mathrm{NaCl} \quad 1 \%(\mathrm{p} / \mathrm{v})$

$\mathrm{pH} 7,0$

Meio LB ágar

Meio LB + Ágar bacteriológico 1,4\% (p/v)

Meio SB (Super Broth)

Peptona de caseína $\quad 3 \%(\mathrm{p} / \mathrm{v})$

Extrato de levedura $2 \%(\mathrm{p} / \mathrm{v})$

MOPS $\quad 1 \%(\mathrm{p} / \mathrm{v})$

\section{Meio SOB}

Bacto-triptona $\quad 2 \%(\mathrm{p} / \mathrm{v})$

Extrato de levedura $\quad 0,5 \%(\mathrm{p} / \mathrm{v})$

$\mathrm{NaCl} \quad 0,06 \%(\mathrm{p} / \mathrm{v})$

$\mathrm{KCl} \quad 0,002 \%(\mathrm{p} / \mathrm{v})$ 
$\mathrm{pH} \mathrm{7,0}$

Meio SOC

Meio SOB $\quad 98 \mathrm{ml}$

Solução estoque de $\mathrm{Mg}^{2+} 2 \mathrm{M} \quad 1 \mathrm{ml}$

Solução estoque de glicose $2 \mathrm{M} \quad 1 \mathrm{ml}$

Solução estoque de glicose $2 \mathrm{M}$

Esterilizada por filtração e estocada a $4{ }^{\circ} \mathrm{C}$

Solução de estoque de Mg 2M

$\mathrm{MgCl}^{2} \quad 1 \mathrm{M}$

$\mathrm{MgSO}^{4} \quad 1 \mathrm{M}$

Esterilizada por filtração e estocada a $4{ }^{\circ} \mathrm{C}$

\section{Antibióticos}

- Ampicilina, Tetraciclina e Cloranfenicol

Os antibióticos liofilizados foram ressuspendidos em água MiliQ na concentração de 20mg/mL. Após a ressuspensão, foram esterilizados por filtração em membrana Millipore de $0,22 \mu \mathrm{m}$ e então estocados a $-4^{\circ} \mathrm{C}$ (ampicilicina e tetraciclina) ou $-20^{\circ} \mathrm{C}$ (cloranfenicol) protegidos da luz. Antibióticos esses utilizados como marca de seleção para plasmídeos transformados em células de E. coli (XL1 blue e BL21(DE3)p LysS).

\section{Solução de IPTG}

Solução de isopropil-tio- $\beta$-D-galactosídeo (IPTG) dissolvido em água em solução estoque de $100 \mathrm{mM}$ e esterilizado por filtração em membrana Millipore de 0,22 $\mu \mathrm{m}$.

\subsubsection{Soluções para extração de DNA plasmidial caseira}

\section{Solução I}

Tris- $\mathrm{HCl} \mathrm{pH} 8,0 \quad 25 \mathrm{mM}$

EDTA pH 8,0 $\quad 10 \mathrm{mM}$ 
Glicose $\quad 50 \mathrm{mM}$

\section{Solução II}

$\mathrm{NaOH} \quad 0,2 \mathrm{M}$

SDS $\quad 1,0 \%(\mathrm{p} / \mathrm{v})$

\section{Solução III}

Acetato de potássio $3 \mathrm{M}$

Ácido Acético $2 \mathrm{M}$

pH ajustado para 4,8 - 5,0

RNAse A

RNAse A (Invitrogen $\left.{ }^{\circledR}\right)$.

\section{Clorofane}

Fenol equilibrado em pH 7,6 1 v

Clorofórmio $\quad 1 \mathrm{v}$

B-hidroxiquinilona $\quad 0,05 \%(\mathrm{p} / \mathrm{v})$

Equilibrado com 0,1 v de Tris-HCl 100 mM pH 7,6

\section{Clorofil}

Clorofórmio $24 \mathrm{v}$

Álcool isoamílico $1 \mathrm{v}$

Equilibrado com 0,25 v de tampão TE

Etanol 100\% 
Etanol $\quad 100 \%(\mathrm{v} / \mathrm{v})$

Etanol 70\%

Etanol $\quad 70 \%(\mathrm{v} / \mathrm{v})$

Isopropanol $100 \%$

Isopropanol $\quad 100 \%(\mathrm{v} / \mathrm{v})$

Acetato de sódio 3 M, pH 4,8

Utilizada para precipitação de DNA em preparação de pequena escala.

5.1.4 Soluções e reagentes para eletroforese em gel de agarose e poliacrilamida

Tampão de corrida TEB 10X pH 8

Trizma base $\quad 0,89 \mathrm{M}$

Ácido bórico $\quad 0,89 \mathrm{M}$

EDTA $\quad 0,02 \mathrm{M}$

dH2O q.s.p $\quad$ 1L

Tampão de corrida TAE 50X pH 8

Tampão Tris-Acetato 2M

Trizima-base $\quad 242 \mathrm{~g}$

Ácido Acético Glacial 57,10ml

EDTA pH $8 \quad 0,05 \mathrm{M}$

dH2O q.s.p $\quad 1 \mathrm{~L}$

Colunas para extração de DNA de gel de agarose para FreezeSqueeze

Ultrafree DA Centrifugal Unit (Millipore®)

Solução de brometo de etídeo $20.000 X$

Brometo de etídeo $\quad 10 \mathrm{mg} / \mathrm{mL}$ 
Tampão de corrida SDS-PAGE

Trizima base $\quad 125 \mathrm{mM}$

Glicina $\quad 125 \mathrm{mM}$

SDS $\quad 0,5 \%(\mathrm{p} / \mathrm{v})$

Tampão de amostra 5X SDS-PAGE

Tris- $\mathrm{HCl} \mathrm{pH} 6,8 \quad 250 \mathrm{mM}$

SDS $\quad 10 \%(\mathrm{p} / \mathrm{v})$

Glicerol $\quad 50 \%(\mathrm{v} / \mathrm{v})$

$\beta$-mercaptoetanol $10 \%(\mathrm{v} / \mathrm{v})$

Azul de bromofenol $\quad 0,5 \%(\mathrm{p} / \mathrm{v})$

Acrilamida 30\% (29:1)

Acrilamida $\quad 145 \mathrm{~g}$

Bis-acrilamida $\quad 5 \mathrm{~g}$

$\mathrm{dH}_{2} \mathrm{O}$ q.s.q. $\quad 500 \mathrm{ml}$

Estocar a $4{ }^{\circ} \mathrm{C}$ ao abrigo da luz.

Tris-HCl 1.5M pH 8,8

Tris $\quad 36,34 \mathrm{~g}$

$\mathrm{dH}_{2} \mathrm{O}$ q.s.q. $\quad 200 \mathrm{ml}$

Tris-HCl 0,5M pH 6,8

Tris $\quad 12,11 \mathrm{~g}$

$\mathrm{dH}_{2} \mathrm{O}$ q.s.q. $\quad 200 \mathrm{ml}$

APS $10 \%(p / v)$

Persulfato de amônio $100 \mathrm{mg} / \mathrm{ml}$

TEMED $(\mathbf{N}, \mathbf{N}, \mathbf{N}, \mathbf{N})$ - tetrametiletilenodiamina 
Gel concentrador 5\% SDS-PAGE

Solução de acrilamida/bis-acrilamida (29:1) $\quad 3,4 \mathrm{ml}$

Tris- $\mathrm{HCl} \mathrm{pH} 6,8 \quad 0,83 \mathrm{ml}$

SDS $\quad 50 \mu 1$

APS $\quad 50 \mu 1$

TEMED $\quad 5 \mu \mathrm{l}$

Gel separador 12\% SDS-PAGE

Solução de acrilamida/bis-acrilamida (29:1) 3,3 ml

Tris-HCl pH 8,8 $4 \mathrm{ml}$

SDS $\quad 100 \mu 1$

APS $\quad 100 \mu \mathrm{l}$

TEMED $\quad 4 \mu \mathrm{l}$

Tampão TE

Tris-HCl pH 8,0 $10 \mathrm{mM}$

EDTA pH 8,0 $1 \mathrm{mM}$

Tampão Tris

Tris- $\mathrm{HCl} \mathrm{pH} \mathrm{8,0} \quad 10 \mathrm{mM}$

5.1.5 Marcadores moleculares para DNA e proteína

$1 \mathrm{~kb}$ plus DNA Ladder (Invitrogen ${ }^{\circledR}$ )

High Mass DNA Ladder (Invitogen $®)$ 
BenchMark ${ }^{\mathrm{TM}}$ Protein Ladder (Invitrogen ${ }^{\circledR}$ )

BenchMark $^{\mathrm{TM}}$ Pre-stained Ladder (Invitrogen ${ }^{\circledR}$ )

\subsubsection{Kits}

QIAGEN Plasmid Miniprep Kit (100) - para extração plasmidial em pequena escala

QIAGEN Plasmid Midiprep Kit (100) - para extração plasmidial em média escala

\subsubsection{Enzimas e tampões}

Cfr9I (XmaI) (10X Cfr9I buffer)

Pfl23II (BsiWI) (10X Tango buffer)

NcoI (10X Cutsmart ${ }^{\circledR}$ buffer)

EcoRI (10X NEBuffer 2.1)

PvuII (10X NEBuffer 3.1)

T4 DNA ligase (5X buffer)
10U/ $\mu \mathrm{l}$ (Thermo Scientific)

2U/ $\mu$ l (Thermo Scientific)

$10 \mathrm{U} / \mu \mathrm{l}($ Biolabs $)$

10U/ $\mu \mathrm{l}$ (Biolabs)

10U/ $\mu \mathrm{l}$ (Biolabs)

$5 \mathrm{U} / \mu \mathrm{l}\left(\right.$ Invitrogen $\left.{ }^{\circledR}\right)$

5.1.8 Soluções para células eletrocompetentes e choque térmico

Glicerol - Solução estoque

Glicerol $50 \%(\mathrm{v} / \mathrm{v})$

\section{Cubetas de eletroporação}

(Gene Pulser/MicroPulserCuvettes, Biorad®)

\section{Solução de $\mathrm{CaCl}_{2}$}

$\mathrm{CaCl}_{2} \quad 50 \mathrm{mM}$

Esterilizada por filtração e estocada a $4^{\circ} \mathrm{C}$

5.1.9 Soluções e tampões para Western Blot

Tampão PBS (Phosphate-Buffered Saline) 10X, pH 7,4 
$\mathrm{NaCl} \quad 1,5 \mathrm{M}$

$\mathrm{Na}_{2} \mathrm{HPO}_{4} \quad 0,1 \mathrm{M}$

$\mathrm{NaN}_{3} \quad 0,02 \%(\mathrm{p} / \mathrm{v})$

Tampão PBST 1X, pH 7,4

PBS $1 X$ acrescido de Tween 20 na concentração final de $0,1 \%$ (v/v)

Solução descorante para coloração com Comassie

Metanol 20\% (v/v)

Ácido acético $\quad 5 \%(\mathrm{v} / \mathrm{v})$

Tampão de transferência semi-seca

Trizima-base $\quad 48 \mathrm{mM}$

Glicina $\quad 39 \mathrm{Mm}$

SDS $\quad 0,037 \%(\mathrm{p} / \mathrm{v})$

Metanol 20\% (v/v)

Tampão de fosfatase alcalina (APB)

Tris- $\mathrm{HCl} \mathrm{pH} 9,5 \quad 100 \mathrm{mM}$

$\mathrm{NaCl} \quad 100 \mathrm{mM}$

$\mathrm{MgCl}_{2} \quad 5 \mathrm{mM}$

Solução de Bloqueio

Leite em pó desnatado 5\% (p/v)

Dissolvido em PBST 1X

Membrana de Nitrocelulose

Hybond-C Extra (Amersham ${ }^{\circledR}$ Bioscience) 


\subsubsection{Anticorpos}

IgG humana Pierce® - Thermo Scientific

IgG de coelho - Thermo Scientific

Anti-IgG humana - Anticorpo com fosfatese alcalina produzido em bode - SIGMA

Anti-IgG de coelho - Anticorpo com fosfatese alcalina produzido em bode - SIGMA

\subsection{MÉTODOS}

\subsubsection{Preparação de DNA plasmidial.}

\section{Em pequena escala (adaptado de Sambrook e Russel, 2001).}

1. Aproximadamente $5 \mathrm{~mL}$ de cultura de células de $E$. coli, transformadas com o plasmídeo de interesse, crescidas em meio LB/Amp $(150 \mu \mathrm{g} / \mathrm{mL})$ durante 16 horas a $37^{\circ} \mathrm{C}$, foram coletados por meio de duas centrifugações de $5 \mathrm{~min}$ a $5.000 \mathrm{rpm}$ em microtubos de $1,5 \mathrm{~mL}$, sendo o sobrenadante desprezado a cada centrifugação.

2. O sedimento foi ressuspendido em $200 \mu \mathrm{L}$ de Solução I. Incubava-se as amostras no gelo por $5 \mathrm{~min}$.

3. Adicionadou-se $400 \mu \mathrm{L}$ de Solução II e as amostras eram homogeneizadas, por meio de inversão do tubo várias vezes, e estas eram incubadas à temperatura ambiente por 5 min.

4. Eram então adicionados $300 \mu \mathrm{L}$ de Solução III, o mesmo procedimento de homogeneização era repetido, e as amostras eram incubadas no gelo por $10 \mathrm{~min}$.

5. As amostras foram centrifugadas a $12.000 \mathrm{rpm}$ por 15 min a $4{ }^{\circ} \mathrm{C}$.

6. Ao sobrenadante foi adicionado $5 \mu \mathrm{L}$ de RNAse A e incubava-se por 1 hora a $37^{\circ} \mathrm{C}$.

7. Em seguida adicionadou-se $300 \mu \mathrm{L}$ de clorofane e, após forte homogeneização, as amostras eram centrifugadas por $5 \mathrm{~min}$ a $5.000 \mathrm{~g}$ à temperatura ambiente, a fase aquosa era coletada para outro tubo. 
8. Posteriormente adicionou-se $300 \mu \mathrm{L}$ de clorofil e o mesmo procedimento anterior de para homogeneizar as amostras, em seguida os passos de centrifugação e coleta eram repetidos.

9. Em seguida foram adicionados $2 \mathrm{v}$ de etanol absoluto gelado e as amostras eram incubadas a $-20{ }^{\circ} \mathrm{C}$ por no mínimo 2 horas.

10. As amostras foram centrifugadas a $12.000 \mathrm{rpm}$ por $45 \mathrm{~min} \mathrm{a} 4^{\circ} \mathrm{C}$. O sobrenadante era desprezado.

11. Finalmente adicionou-se $1 \mathrm{~mL}$ de etanol $70 \%$ gelado e as amostras eram novamente centrifugadas a $12.000 \mathrm{rpm}$ por $15 \mathrm{~min}$ a $4{ }^{\circ} \mathrm{C}$. O sobrenadante era desprezado.

12. O sedimento foi seco a vácuo ou por simples exposição ao ar e ressuspendido em $50 \mu \mathrm{L}$ de TE ou água MiliQ e as amostras conservadas a $-20^{\circ} \mathrm{C}$.

\subsubsection{Preparação de células competentes e transformação bacteriana.}

\section{Por choque térmico-CaCl (adaptado de Maranhão, 2003).}

1. Foram inoculados $500 \mu \mathrm{L}$ de um pré-inóculo, feito a partir de uma colônia isolada da célula de interesse, em $50 \mathrm{~mL}$ de meio LB. O inóculo foi incubado a $37^{\circ} \mathrm{C}$ a $220 \mathrm{rpm}$ até a cultura atingir uma densidade óptica a 600nm (OD600) de 0,1 a 0,3.

2. Centrifugou-se o inóculo a 3.000 x $g$ por 15 min a $4{ }^{\circ} \mathrm{C}$, o sobrenadante era desprezado. (Após essa etapa é importante que em todas as etapas subsequentes as células sejam mantidas resfriadas para evitar uma perda de eficiência).

3. O sedimento foi ressuspendido em $10 \mathrm{~mL}$ de solução de $\mathrm{CaCl} 250 \mathrm{mM}$ estéril gelada, com movimentos suaves.

4. Centrifugou-se novamente a solução a 3.000 x $g$ por 15 min a $4{ }^{\circ} \mathrm{C}$, o sobrenadante era desprezado. 
5. O sedimento foientão ressuspendido em $1 \mathrm{~mL}$ de solução de $\mathrm{CaCl} 250 \mathrm{mM}$ estéril gelada, com movimentos suaves.

6. Após incubação de 1 hora em banho de água/gelo, as células eram aliquotadas e estas podiam ser utilizadas por um período máximo de 24 horas.

7. Eram incubados de 100 a $200 \mu \mathrm{L}$ de célula competente com o plasmídeo de interesse a ser transformado em banho de água/gelo por $30 \mathrm{~min}$.

8. O choque térmico foi realizado por meio de incubação do sistema de transformação em banho a $42{ }^{\circ} \mathrm{C}$ por $3 \mathrm{~min}$.

9. Adicionou-se imediatamente $1 \mathrm{~mL}$ de meio $\mathrm{LB}$ e o sistema foi incubado por $1 \mathrm{~h} \mathrm{a} 37^{\circ} \mathrm{C}$.

10. Foram semeadas quantidades variáveis do sistema de transformação em placas contendo meio LB-ágar contendo ampicilina a $150 \mu \mathrm{g} / \mathrm{mL}$. As placas eram mantidas na estufa a $37^{\circ} \mathrm{C}$ por 16 horas.

\section{Por eletroporação (adaptado de Maranhão, 2003).}

1. Uma colônia isolada da célula de interesse foi inoculada em $10 \mathrm{~mL}$ de meio SB contendo o antibiótico de interesse. Esse pré-inóculo foi mantido a $37^{\circ} \mathrm{C}$ sob agitação de $220 \mathrm{rpm}$ por 16 horas.

2. Posteriormente, inoculou-se $1 \mathrm{~mL}$ do pré-inóculo em $500 \mathrm{~mL}$ de meio $\mathrm{SB}$ contendo 2,5 mL da solução estoque de glicose $2 \mathrm{M}$ e 2,5 mL da solução estoque de $\mathrm{Mg} 2 \mathrm{M}$. O inóculo era incubado a $37^{\circ} \mathrm{C}$ a $220 \mathrm{rpm}$ até a cultura atingir uma OD600 de 0,7 a 0,9.

3. O inóculo foi então centrifugado a 3.000 x $g$ por 20 min a $4{ }^{\circ} \mathrm{C}$, e o sobrenadante desprezado e a célula era mantida sempre gelada a partir desse momento.

4. O sedimento foi ressuspendido em $25 \mathrm{~mL}$ de glicerol $10 \%$ estéril gelado e a seguir adicionou-se mais $75 \mathrm{~mL}$ de glicerol $10 \%$ gelado. 
5. Em seguida outra centrifugação a $3.000 \mathrm{x} g$ por $20 \mathrm{~min}$ a $4{ }^{\circ} \mathrm{C}$, repetindo a etapa anterior.

6. O sedimento era então ressuspendido em $25 \mathrm{~mL}$ de Gilcerol $10 \%$ estéril gelado e submetido a última centrifugação a $3.000 \times \mathrm{x}$ por $20 \min$ a $4{ }^{\circ} \mathrm{C}$.

7. O sedimento final foi ressuspendido em 1 a $2 \mathrm{~mL} \mathrm{de} \mathrm{glicerol} 10 \%$ e as células eram aliquotadas, congeladas em banho de gelo seco com etanol e armazenadas imediatamente a $-80^{\circ} \mathrm{C}$.

8. Para a transformação, o plasmídeo foi adicionado, já em um tubo resfriado previamente, à célula competente e imediatamente colocado na cubeta de eletroporação (BioAgency®) também já resfriada.

9. A eletroporação foi feita seguindo os seguintes parâmetros elétricos: $2,5 \mathrm{kV}, 25 \mu \mathrm{F}$ e $200 \Omega$, no aparelho Gene Pulser com PulserController da BioRad. O $\tau$ esperado nessas condições é de 4,0 a 5,0 milissegundos.

10. Imediatamente após o choque a cubeta lavou-se com $3 \mathrm{~mL}$ de meio SOC e transferiu-se o meio recolhido para um tubo de centrifugação de $50 \mathrm{~mL}$.

11. Após uma incubação de $1 \mathrm{~h}$ a $37^{\circ} \mathrm{C}$ e $220 \mathrm{rpm}$, diluições da transformação foram semeadas em placas contendo ampicilina a $200 \mu \mathrm{g} / \mathrm{mL}$ e as placas mantidas na estufa a $37^{\circ} \mathrm{C}$ por 16 horas.

\subsubsection{Obtenção das sequências de Vh e VpreBJ (SLC)}

\subsubsection{Sequêncais dos Vhs}

As sequências das famílias de VH10 e VH4 foram retiradas de uma biblioteca de sequências montada em trabalhos anteriores (GUEDES, 2009).

\subsubsection{Cadeia similar a SLC, VpreBJ}

Foi desenhada uma cadeia leve similar a cadeia leve característica de células B em desenvolvimento (SLC), completando a formação das sequências que codificarão as 
moléculas scFvs. A SLC é codificada por dois genes diferentes que são transcritos no estágio pré - B dessas células (Martensson e Almqvist., 2012). O modelo da scFv resultante é reportado no artigo de Morstadt et al. (2008), no qual um scFv recombinante com VpreBJ é construído para estudo do desenvolvimento de células B. Nesse mesmo trabalho, a cristalografia mostrou que a conformação do scFv montado com esta cadeia, de fato remonta os aspectos de um anticorpo normal dessa região, formando o domínio de imunoglobulina (Ig) responsável pelo reconhecimento de antigênico.

\subsubsection{Síntese dos genes sintéticos}

Os genes Vh foram ligados a cadeia VpreBJ por um segmento que codifica para um linker peptídico de 15 aminiácidos com a repetição dos resíduos GGGGS x 3. Após o desenho dos 4 genes que codificam para quatro scFvs diferentes, as sequências foram enviadas para a síntese pela empresa GenScript ${ }^{\circledR}$, produzidas quimicamente e clonadas no vetor puc57.

\subsubsection{Clonagens}

Os scFvs sem modificação foram nomeados de acordo com o segmento $\mathrm{V}$ que carregam, VH10 e VH4 (originais), e os scFvs com as CDRs trocadas VH10-H24 e VH4H210. Os quatro genes sintetizados estavam em plasmídeos comerciais, esses plasmídeos não são apropriados para a expressão gênica, tendo sido aproveitados somente a origem de replicação (oriC) e o gene de resistência a ampicilina (bla) para a seleção. Deste modo, fez-se necessária a realocação por clonagem gênica desses segmentos em um plasmídeo de expressão. Nós utilizamos o plasmídeo pIg16 para a expressão bacteriana. Esses plasmídeos contêm não somente oriC e gene de resistência para ampicilina, como também um promotor para a expressão da proteína de interesse e sítios úteis para pareamento de primers universais para sequenciamento (T7 e SP6).

O segmento de interesse foi retirado do plasmídeo comercial pela digestão primariamente simples com XmaI (Cfr9I) e NcoI em dois tubos separados, à $37^{\circ} \mathrm{C}$ overnight, posteriormente retirou-se uma alíquota dessas digestões para observação da digestão no gel de agarose, confirmada a digestão as amostras foram precipitadas para a obtenção do segmento linearizado, após ressuspendê-los em água miliQ, a segunda enzima de restrição foi adicionada aos tubos junto com todo sistema e deixada novamente overnight para a digestão completa dos segmentos. 


\begin{tabular}{|c|c|}
\hline DNA & $5 \mu \mathrm{l}(\sim 10 \mu \mathrm{g})$ \\
\hline $\mathrm{H} 2 \mathrm{O}$ & $6,5 \mu \mathrm{l}$ \\
\hline Tampão 1X & $1,5 \mu \mathrm{l}$ \\
\hline Enzima & $2 \mu \mathrm{l}$ \\
\hline Vol.Total & $15 \mu \mathrm{l}$ \\
\hline
\end{tabular}

Tabela 2. Sistema de digestão de plasmídeos provenientes de MidiPrep (QIAGEN).

Depois da segunda digestão, foi feita uma nova análise por gel de agarose com uma alíquota de $1 \mu$ para a confirmação da digestão pelas duas enzimas, resultando na liberação das bandas esperadas. Foram então feitos dois géis de agarose para a eluição das amostras, um para o vetor $(0.8 \%)$ e outro para o inserto (1.2\%). Adicionou-se tampão (azul de bromofenol) às amostras que em seguida foram aplicadas no gel de eluição, submetido a uma corrente constante de 30 Volts durante a corrida de duração de 6 horas. Em seguida, as amostras foram levadas ao transluminador UV onde se identificou as bandas de interesse, foram recortadas as bandas dos géis e prontamente estocadas a $-20^{\circ} \mathrm{C}$. Após o congelamento esse material passou por processo conhecido como freeze squeeze, que consiste na maceração seguida da centrifugação do material congelado em colunas (Ultrafree DA Centrifugal Unit Millipore®), essas colunas possuem um filtro que barra a agarose, porém permitem a passagem do DNA, as amostras do vetor e inserto foram tratadas separadamente. Posteriormente o material recuperado foi precipitado pela adição de 2,5V de etanol 100\% e 10\% de acetato de sódio $\left(\mathrm{C}_{2} \mathrm{H}_{3} \mathrm{NaO}_{2}\right) 3 \mathrm{M}$ e estocado a $-20^{\circ} \mathrm{C}$ por 2 horas, passado o tempo de precipitação centrifugou-se as amostras $\left(12.000 \mathrm{~g}\right.$ por $45 \mathrm{~min}$ a $\left.4^{\circ} \mathrm{C}\right)$, descartou-se o sobrenadante e lavouse as amostras com etanol $70 \%$ sendo em seguida centrifugadas novamente $(12.000 \mathrm{~g}$ por 15 min a $4{ }^{\circ} \mathrm{C}$ ), o sobrenadante foi rapidamente descartado e a amostra na forma de pellet nem sempre visível foi deixada para secar pela simples exposição ao ar, finalmente as amostras foram ressuspendidas em água miliQ e quantificadas por gel de agarose, utilizando-se o marcador High Mass (Invitrogen ${ }^{\circledR}$ ) e o aparelho Nanodrop para comparação, a partir deste momento as amostras estavam prontas para compor os sistemas de ligação.

A quantidade de DNA utilizado na ligação foi obtida pela fórmula:

$$
\frac{\text { Vetor }(\mathrm{ng}) \mathrm{x} \text { inserto }(\mathrm{kb})}{\text { vetor }(\mathrm{kb})}=\mathrm{ng} \text { do inserto }
$$


Esse cálculo permite a obtenção da quantidade de material a ser utilizada no sistema de ligação baseado na molaridade de 1:1 dessas moléculas, já que o tamanho do vetor neste caso é maior que o tamanho do inserto, a proporção correta entre o número de moléculas do vetor e inserto são cruciais para o êxito da clonagem gênica. O sistema de ligação utilizado na primeira clonagem e no segundo conjunto de clonagens é detalhado na tabela abaixo:

Clonagem 1

\section{Clonagem 2}

$1: 0$
$1: 0$

$1: 5$

\begin{tabular}{|l|c|c|l|l|l|c|}
\hline Vetor & $\begin{array}{l}3,5 \mu \mathrm{l} \\
(\sim 105 \mathrm{ng})\end{array}$ & $3,5 \mu \mathrm{l}(\sim 105 \mathrm{ng})$ & Vetor & $\begin{array}{l}5 \mu \mathrm{l} \\
(\sim 75 \mathrm{ng})\end{array}$ & $5 \mu \mathrm{l}(\sim 75 \mathrm{ng})$ \\
\hline Inserto & - & $4,7 \mu \mathrm{l}(\sim 118 \mathrm{ng})$ & & Inserto & - & $3 \mu \mathrm{l}(\sim 30 \mathrm{ng})$ \\
\hline Ligase & $1 \mu \mathrm{l}$ & $1 \mu \mathrm{l}$ & Ligase & $1 \mu \mathrm{l}$ & $1 \mu \mathrm{l}$ \\
\hline Tampão & $2 \mu \mathrm{l}$ & $2 \mu \mathrm{l}$ & Tampão & $2 \mu \mathrm{l}$ & $2 \mu \mathrm{l}$ \\
\hline $\mathrm{H}_{2} \mathrm{O}$ & $4,7 \mu \mathrm{l}$ & - & H2O & $3 \mu \mathrm{l}$ & $3 \mu \mathrm{l}$ \\
\hline Vol.Total & $11,2 \mu \mathrm{l}$ & $11,2 \mu \mathrm{l}$ & & Vol.Total & $11 \mu \mathrm{l}$ & $11 \mu \mathrm{l}$ \\
\hline
\end{tabular}

Tabela 3. Sistemas de ligação utilizados nas clonagens.

Os sistemas de ligação foram mantidos a temperatura de $4^{\circ} \mathrm{C}$ overnight, transformados por eletroporação (Gene Pulser Xcell ${ }^{T M}$ Electroporation System Bio-Rad ${ }^{\circledR}$ ) em cepas de XL1 blue e plaqueados em LB ágar com ampicilina $(150 \mathrm{ug} / \mathrm{ml})$, cultivou-se as placas a $37^{\circ} \mathrm{C}$ overnight. Após comparação com o controle negativo, que apresentava somente o vetor (1:0), as placas com poucas colônias no controle negativo em relação à ligação completa (1:5) foram escolhidas e tiveram suas colônias coletadas para preparação do inóculo e extração do DNA por miniprep caseira. Quantificou-se as amostras para o seu uso no screening por digestão para a confirmação da clonagem, as amostras que apresentassem resultado positivo tinham suas células cultivadas novamente e uma nova miniprep (QIAGEN Plasmid Midiprep Kit (100)) foi realizada e as amostras obtidas enviadas para sequenciamento (Sanger).

As etapas detalhadas acima foram repetidas nas outras clonagens, porém, essas clonagens eram dependentes da primeira pelo fato do primeiro segmento clonado ser o único a apresentar a região completa para a formação do $\mathrm{scFv}$, enquanto os outros segmentos eram compostos apenas de parte da cadeia pesada, que compreende o início da cadeia até o final da 
CDR2, essa região é intercalada pelos sítios de XmaI e BsiWI respectivamente, sendo assim, o arcabouço formado na primeira clonagem foi necessário para a clonagem das três sequências restantes.

\subsubsection{Expressão em E.coli}

\subsubsection{Verificação da expressão no vetor $\operatorname{pIg} 16$}

Para a verificação da expressão das proteínas de interesse foram utilizadas cepas de BL21(DE3) pLysS com resistência a cloranfenicol. Essas células bacterianas são modificadas para a otimização da produção de proteínas heterólogas, sendo o processo induzido principalmente pela adição de IPTG no meio de cultura. Os plasmídeos foram transformados em BL21 por choque térmico segundo o procedimento do item 5.2.2.1 e as células cultivadas em placas de LB ágar com ampicilina $(150 \mu \mathrm{g} / \mathrm{ml})$ e cloranfenicol $(10 \mu \mathrm{g} / \mathrm{ml})$ overnight. No dia seguinte, foram feitos pré-inóculos, colocando-se uma colônia coletada dessas placas em $5 \mathrm{ml}$ de meio LB com ampicilina $(150 \mu \mathrm{g} / \mathrm{ml})$ e cloranfenicol $(10 \mu \mathrm{g} / \mathrm{ml})$ cultivados no shaker à $37^{\circ} \mathrm{C}$ e $250 \mathrm{rpm}$ overnight, no dia seguinte coletou-se uma alíquota de $500 \mu \mathrm{l}$ que foi adicionada a $25 \mathrm{ml}$ de meio LB com ampicilina $(150 \mu \mathrm{g} / \mathrm{ml})$ e cloranfenicol $(10 \mu \mathrm{g} / \mathrm{ml})$. O inóculo foi mantido no shaker à $37^{\circ} \mathrm{C} 250 \mathrm{rpm}$ até atingir uma densidade óptica (DO) de cerca 0.8 , neste momento foi adicionado IPTG nas concentrações de $0.1,0.5$ e $1 \mathrm{mM}$ para a indução da expressão do plasmídeo VH10, para os outros plasmídeos a indução foi feita apenas na concentração de $0.5 \mathrm{mM}$ de IPTG, porém antes da adição, uma alíquota de $1 \mathrm{ml}$ foi retirada para controle. O período de indução foi entre 4 e 5 horas, passado esse tempo foi retirada outra alíquota de $1 \mathrm{ml}$ do meio. As duas alíquotas foram centrifugadas e o meio descartado, sendo os pellets estocados a $-20^{\circ} \mathrm{C}$.

Os pellets foram então ressuspendidos em $40 \mu \mathrm{l}$ de tampão de amostra 5X e colocados em água fervente por 5 minutos. Também foram feitos géis de poliacrilamida $12 \%$. Da amostra total entre 2-5 $\mu$ l eram aplicados nos poços. O gel foi submetido a uma corrente de 30 mA e a uma voltagem máxima de 300 volts por 2 horas em média.

\subsubsection{Expressão de proteínas solúveis}

Depois da confirmação da expressão das proteínas de interesse após a transformação dos plasmídeos e indução, nós focamos nossos esforços na otimização da expressão e recuperação dessas proteínas de modo que estivessem solúveis e funcionalmente ativas. 
Diferentemente da abordagem anterior, na qual todo o extrato celular foi lisado e aplicado no gel para a visualização da expressão, nessa etapa nós seguimos um protocolo diferente para a obtenção dessas proteínas. O mesmo procedimento utilizado na etapa inicial para a transformação dos plasmídeos em BL21 se repete aqui, já para a indução nós estipulamos três concentrações de IPTG $(0.1 ; 0.2$ e $0.5 \mathrm{mM})$ e duas temperaturas $\left(16^{\circ} \mathrm{C}\right.$ e $\left.37^{\circ} \mathrm{C}\right)$ para cada construção, visando estabelecer os melhores parâmetros para a expressão dos scFvs solúveis.

A adição de IPTG chegada a DO de 0.8 foi seguida de um tempo de indução de 18 horas para ensaios realizados à $16^{\circ} \mathrm{C}$ e $4-5$ horas para induções à $37^{\circ} \mathrm{C}$. Alíquotas de $1 \mathrm{ml}$ foram retiradas antes e depois da indução, estas alíquotas e todo o pellet da amostra original foram centrifugadas e o pellet estocado a $-20^{\circ} \mathrm{C}$. No dia seguinte as amostras foram ressuspendidas em $1 \mathrm{ml}$ buffer de lise $(75 \mathrm{mM}$ Tris, $300 \mathrm{mM} \mathrm{NaCl} \mathrm{pH} \mathrm{7,25)} \mathrm{e} \mathrm{sonicadas} \mathrm{para}$ lisar as células. Cada amostra foi colocada em um suporte fixo com gelo e sonicada quatro vezes com uma amplitude 50\% durante 4 minutos e com intervalos de 4 minutos para o resfriamento do material. As amostras eram então centrifugadas a $13.000 \mathrm{rpm}$ por 8 minutos a uma temperatura de $4^{\circ} \mathrm{C}$, sendo mantidas no gelo durante todo processo. Em seguida, coletava-se o sobrenadante que era diluído em tampão de amostra $5 \mathrm{X}$ e estocados a $-20^{\circ} \mathrm{C}$ se houvesse a necessidade, para a aplicação das amostras, elas eram colocadas em água fervente por 5 minutos e aplicadas em géis de poliacrilamida $12 \%$ para a análise de expressão utilizando-se do gel de SDS-PAGE corado com comassie e do resultado do western blot.

\subsubsection{SDS-PAGE}

A técnica de SDS-PAGE (sodium dodecyl sulfate polyacrylamide gel electrophoresis) permite a análise qualitativa de proteínas, sendo útil para a separação das proteínas por tamanho, permitindo também a análise da integridade das proteínas e de sua massa molecular. O SDS é um detergente que junto com um agente redutor para a quebra das pontes dissulfeto,

como $\beta$-mercaptoetanol, desfaz toda a estrutura terciária das moléculas, tornando-as linerizadas (desnaturação). O SDS recobre as proteínas de forma uniforme com uma carga negativa, tornado sua carga aproximadamente proporcional ao seu peso molecular.

Para fazer o SDS-PAGE, primeiramente preparava-se o gel separador de $12 \%$, sendo a polimerização catalisada pela adição de $100 \mu \mathrm{l}$ de APS $10 \%$ e $4 \mu \mathrm{l}$ de TEMED, em seguida colocado na cuba. Seguia-se com a preparação do gel concentrador, para a polimerização $50 \mu 1$ de APS $10 \%$ e $5 \mu \mathrm{l}$ de TEMED. O gel concentrador era aplicado sobre o separador, colocava- 
se então o pente para gerar os poços. Após a polimerização colocava-se a cuba com o gel no aparato de eletroforese de modo que as extremidades do gel ficassem em contato direto com o tampão de corrida 1X. Retirava-se o pente e aplicavam-se as amostras já preparadas anteriormente.

De modo geral, foram adicionadas às amostras o tampão de amostra, em seguida foram colocadas em água fervente por 5 minutos para desnaturação completa das proteínas, posteriormente foram aplicados no gel de 2-4 $\mu$ l por poço para as amostras do extrato celular total, já para as amostras provenientes da sonicação foram aplicados $10 \mu \mathrm{l}$ por poço, já que as amostras estavam mais diluídas. Após a aplicação das amostras nos poços e o fechamento da cuba, a corrente foi ligada em 20mA por gel. A corrida dos géis durou em média 2 horas, o tampão de amostra contendo azul de bromofenol permitiu o acompanhamento da corrida, de modo que quando a banda de coloração do bromofenol que corresponde a $\sim 10 \mathrm{kDa}$ percorria todo o gel, a corrente era cortada e o gel retirado para a coloração ou western blot.

\subsubsection{Coloração do gel}

Para a coloração, os géis foram colocados em uma solução de comassie G em agitação constante por um período entre 2-4h. Passado esse tempo, a solução de comassie G foi descartada e adicionou-se solução descorante que era trocada a cada 1 hora e meia ou deixada overnight, sendo o processo continuado no dia seguinte até que o gel estivesse descorado com as bandas de proteínas visíveis.

\subsubsection{Western blot}

Western blotting é uma técnica utilizada na biologia molecular que permite a identificação de proteínas específicas em uma solução complexa de proteínas. Após a eletroforese, as proteínas são transferidas do gel para uma membrana de nitrocelulose por contato direto e pela passagem de uma corrente elétrica. Após a transferência for completada, a membrana é incubada com anticorpos específicos para a proteína de interesse. Os anticorpos que não se ligarem na proteína ou se ligarem de forma inespecífica em outra região serão excluídos da membrana pelas etapas de lavagem da mesma. A partir deste momento é possível de identificar a localização da banda pela utilização de um anticorpo que permite a revelação da posição de ligação por reações químicas enzima-substrato que geram um produto visível, como uma banda na membrana. Dependendo do alvo escolhido pode ser necessária a 
utilização de um anticorpo secundário que carregue o substrato para a revelação da banda de proteína na membrana (MAHMOOD e YANG, 2012).

Após a eletroforese do gel de poliacrilamida, recortou-se 12 pedaços de papel filtro do tamanho do gel $(8 \mathrm{~cm} \times 7 \mathrm{~cm})$ e um pedaço da membrana de nitrocelulose nas mesmas medidas. As partes recortadas foram então mergulhadas no tampão de transferência, fez-se um 'sanduíche', no qual a membrana e o gel estavam em contato direto no centro, de modo que os papéis filtros, seis de um lado, seis do outro protegiam a membrana e o gel. Esse material foi novamente umidificado com tampão de transferência e o excesso de bolhas retirado por compressão, sendo então levado para um sistema de transferência semi-seca com eletrodos de grafite (Pharmacia-LKB $\AA$ ), onde os eletrodos foram posicionados assegurandose que a membrana estivesse na orientação correta entre o gel e o eletrodo positivo, já que transferência é feita no sentido (-) para (+), submetida a uma corrente elétrica de $45 \mathrm{~mA}(0,8$ $\mathrm{mA} / \mathrm{cm}^{2}$ ) tendo o processo de transferência duração de $1 \mathrm{~h}$ e $45 \mathrm{~min}$.

Após a transferência, a membrana de nitrocelulose agora com as proteínas foi incubada em solução de leite em pó desnatado (5\%) e sob agitação constante por 1 hora, esta etapa conhecida como bloqueio, é importante para evitar ligações não específicas de anticorpos na membrana, já que esta possui uma alta afinidade por proteínas. Em seguida lavou-se a membrana 3 vezes com PBST 1X, e então adicionou-se a solução de anticorpos IgG (humano ou coelho) na concentração de $0,4 \mu \mathrm{g} / \mathrm{ml}$ e agitação constante por 1 hora seguida de 3 lavagens com PBST 1X e adição de um anti-IgG (humano ou coelho) diluído em 1:20.000 incubando-se por mais 1 hora em agitação constante. Lavou-se mais 3 vezes a membrana, e foi adicionada uma rápida lavagem com APB, depois disso adicionou-se $10 \mathrm{ml}$ da solução reveladora (NBT/BCIP). Em menos de 3 minutos em média a membrana estava revelada com as bandas em evidência, a membrana foi lavada com água em abundância, deixada para secar ao ar livre e guardada para análise.

\section{RESULTADOS E DISCUSSÃO}

\subsection{DESENHO DE SEQUÊNCIAS}

Foram escolhidas duas sequências de cadeia pesada, uma baseada na sequência germinal de VH10 e outra de VH4 com um mesmo CDR H3 selecionado a partir da biblioteca em phage display. O critério relevante para a escolha dessas sequências foi a viabilidade de expressão dessas moléculas pelo organismo utilizado na expressão heteróloga. Além dessas 2 
sequências, outras duas sequências foram criadas, nas quais, houve uma troca da região CDR H2 entre as sequências VH10 e VH4 iniciais (Figura 9).

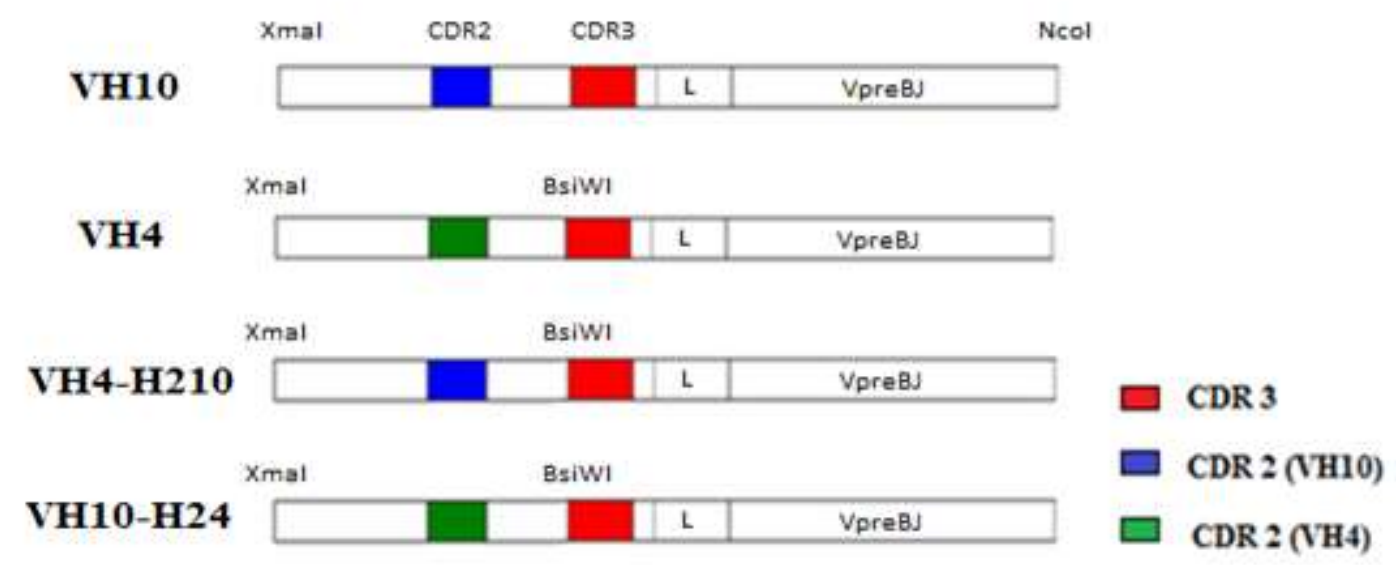

Figura 9: Construções dos genes das famílias VH10 e VH4 e suas variantes de CDR H2 trocadas. A primeira sequência contém além do VH, a parte comum em todas as construções, CDR3H, FW4, linker (L) e a fusão VpreB com $\lambda 5$ (VpreBJ)

Sequências formadoras das cadeias pesadas $(\mathrm{VHs})$ foram sequências germinais murinas montada em trabalhos anteriores do grupo de pesquisa.

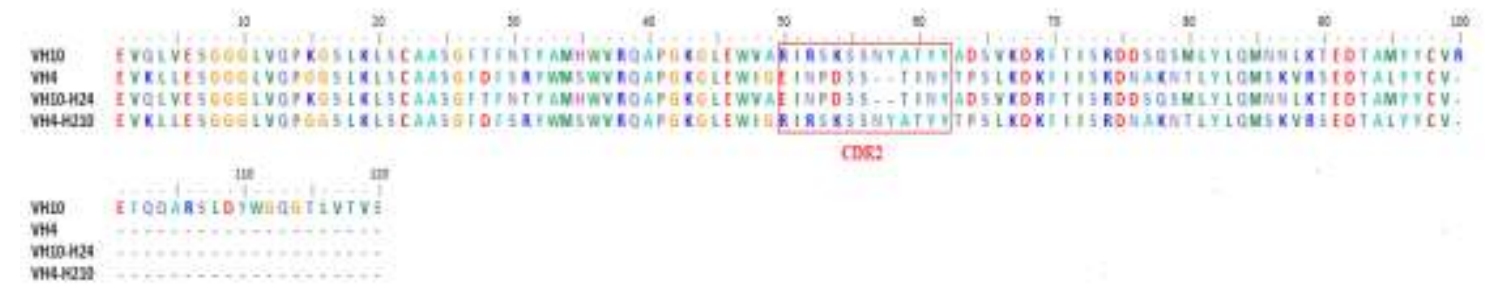

Figura 10. Alinhamento múltiplo (ClustalW/Bioedit) das sequências de germinais das famílias VH4 e VH10 e suas variantes com as CDRs $\mathrm{H} 2$ trocadas.

\section{Obtenção das sequências formadores da cadeia leve do gene recombinante.}

- Sequência murina do gene VpreB1 $\Delta \mathrm{U}$ de imunoglobulina cadeia iota. Em amarelo a região selecionada e em vermelho a região excluída. 


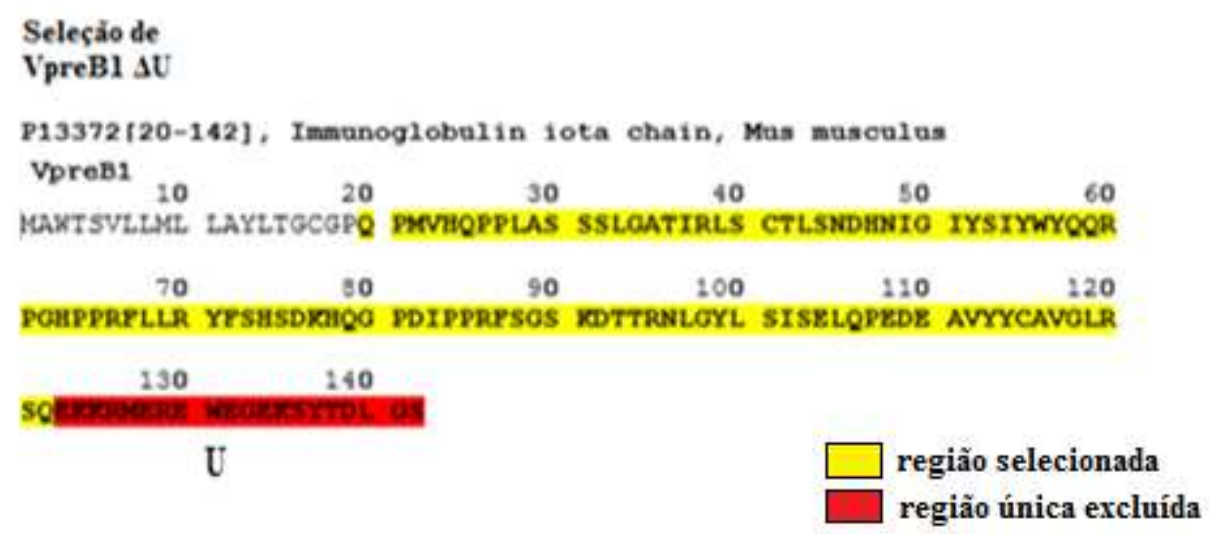

- Sequência murina da região $\mathrm{J}$ de $\lambda 5$. Em amarelo a região selecionada.

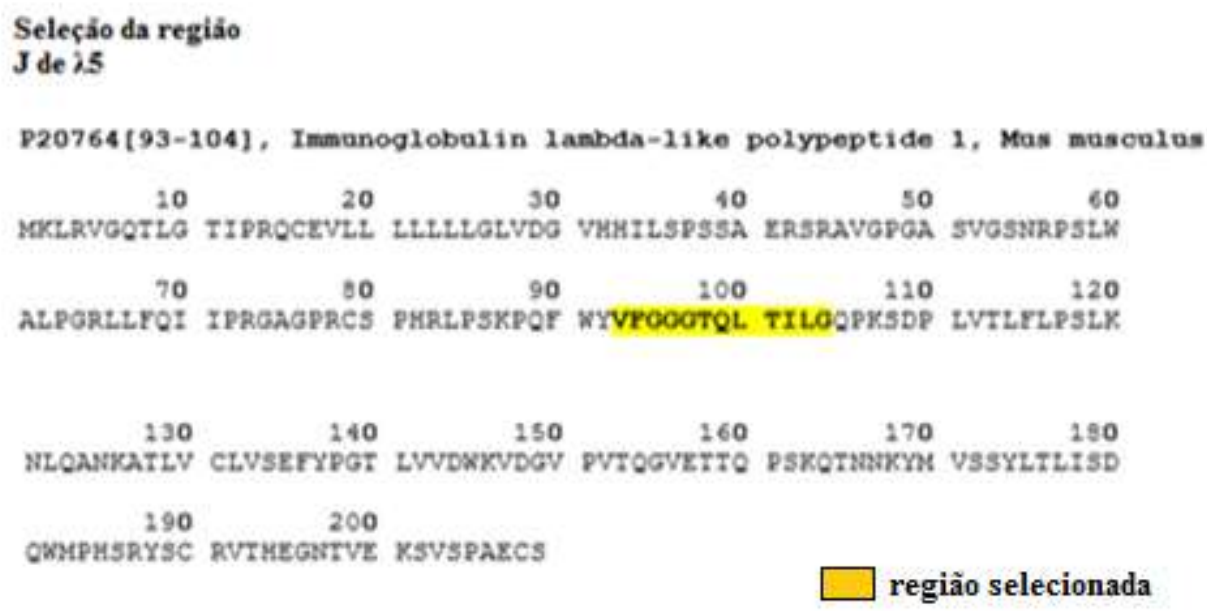

- Fusão VpreB1 + J ( $\lambda 5)$ formando o segmento da cadeia leve utilizadas nos genes recombinantes. Em amarelo a região $\mathrm{VpreB} 1 \Delta \mathrm{U}$ e em verde região J de $\lambda 5$.

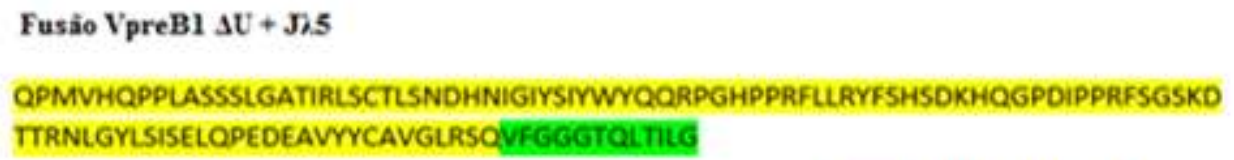

Figura 11: Esquema do desenho da cadeia leve (VpreBJ) expressa em células B murina em desenvolvimento com modificações conforme Morstadt et al (2008).

Em nossa abordagem, diferentemente de Morstadt et al. (2008) que utilizou sequências humanas, utilizamos sequências murinas. As sequências para a região VpreB1 $\Delta U$ $\left(\mathrm{n}^{\circ}\right.$ de acesso X05556) e a região $\mathrm{J}$ de $\lambda 5$ ( $\mathrm{n}^{\circ}$ de acesso AJ852426) foram obtidas no banco de dados biológico Uniprot (http://www.uniprot.org/) (Figura 11), a combinação dessas sequências permitiu a formação de um domínio Ig completo quando ligados com a cadeia 
pesada (Vh). As sequências do VH10 e VH4 citadas anteriormente foram obtidas a partir de uma biblioteca de pesquisas anteriores do nosso laboratório. O codon usage do organismo de expressão utilizado foi obtido no banco de dados Codon Usage Database (http://www.kazusa.or.jp/codon/).

A molécula desenhada por Morstadt et al (2008) foi desenvolvida com o propósito da criação de um modelo de ausência de sinalização pela retirada das regiões únicas de VpreB e $\lambda 5$. Nós utilizamos o mesmo desenho para gerar uma molécula scFv murina estável, baseado nos dados de cristalografia do estudo citado acima, com a mesma molécula. Tal decisão, se apoia no fato de nós acreditarmos que não somente as regiões únicas são responsáveis pela ligação a antígenos próprios gerando sinalização, o que já está demonstrado em vários ensaios (GAUTHIER et al., 2002), como também a estrutura convencional por si só, tem papel fundamental na ligação ao antígeno mesmo em um contexto de pré-BCR, sendo capaz de gerar estímulo necessário para a sinalização ocorrer. Como demonstrado por Kohler et al (2008), BCRs auto-reativos induzem a sinalização autônoma e expansão clonal de células préB de forma similar ao pré-BCR. Ou seja, mesmo na ausência das regiões únicas, que apenas estão presentes no pré-BCR, porém não no BCR de células maduras, um receptor auto-reativo é capaz de mimetizar a sinalização do pré-BCR, gerando a cascata de sinalização necessária para o enriquecimento celular.

\subsection{CLONAGENS}

O plasmídeo de expressão utilizado apresentava sequências formadoras do peptídeo sinal (fragmento de fosfatase alcalina, PhoA) e proteína A que estavam dentro da ORF intercalando a região onde o segmento de interesse seria inserido, essas estruturas irão compor o polipeptídio, atuando no endereçamento da proteína e na purificação, respectivamente. $\mathrm{O}$ gene do scFv VH10 foi desenhado de forma que os sítios de restrição de XmaI e NcoI intercalassem a sua sequência no plasmídeo pIg16, sendo este o segmento que contém toda a informação para a síntese do scFv completo (Figura 9). 


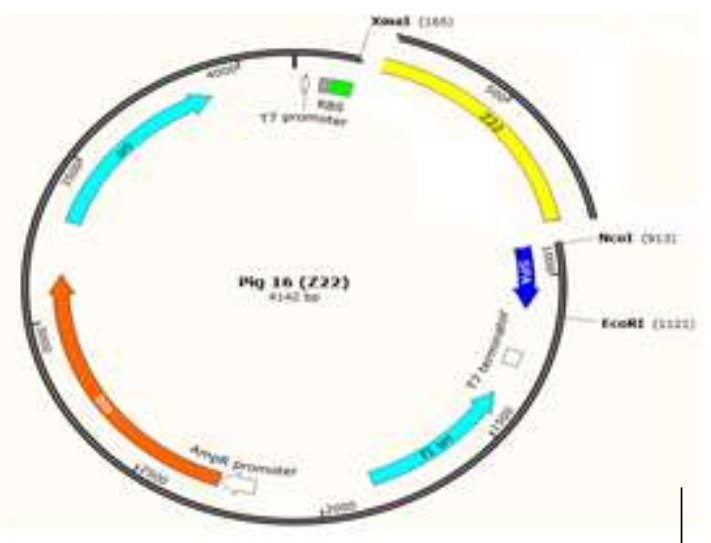

pIg16 (vetor de expressão)

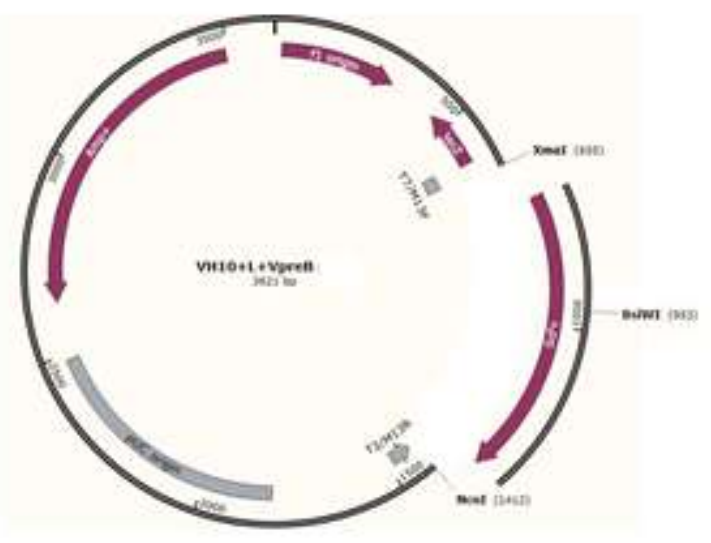

Plasmídeo comercial

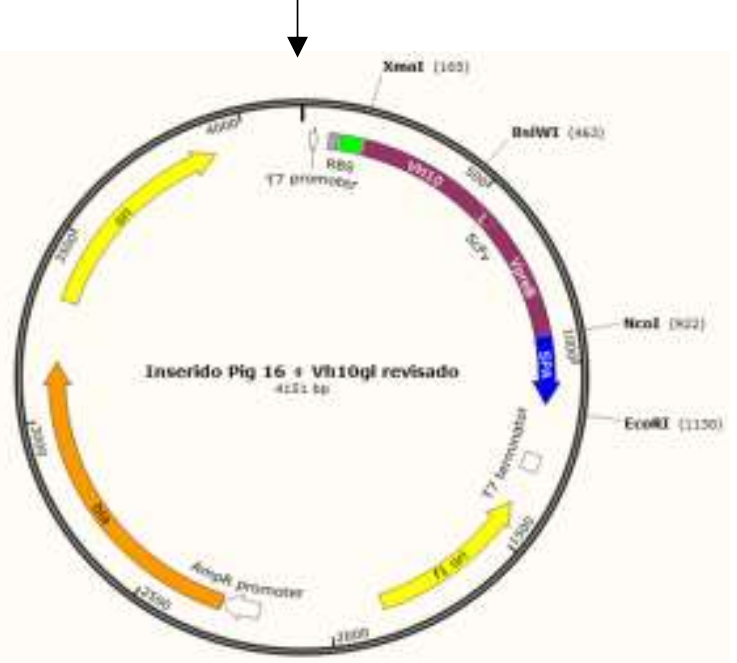

Figura 12. Esquema da primeira clonagem. Liberação do vetor e retirada do inserto com as enzimas XmaI e NcoI seguida da ligação para a formação de um novo plasmídeo (VH10).

Os plasmídeos foram digeridos com XmaI e NcoI para liberação do vetor e retirada do segmento de interesse do plasmídeo comercial (Figura 12). O segmento gênico de interesse para a formação do scFv obtido foi então ligado ao vetor. Após a amplificação e purificação, o material passou por novas digestões para a confirmação da clonagem.

Os plasmídeos provenientes das clonagens foram digeridos com EcoRI e BsiWI, já que o vetor utilizado não possui sítio de corte para BsiWI e o plasmídeo com inserto sintético não possui sítio de corte para EcoRI, apenas plasmídeos que sofreram linearização com as duas enzimas em reações separadas foram considerados clones positivos, o que era esperado após a clonagem (Figura 13). 


\section{VH10 (digerido com EcoRI e BsiWI)}
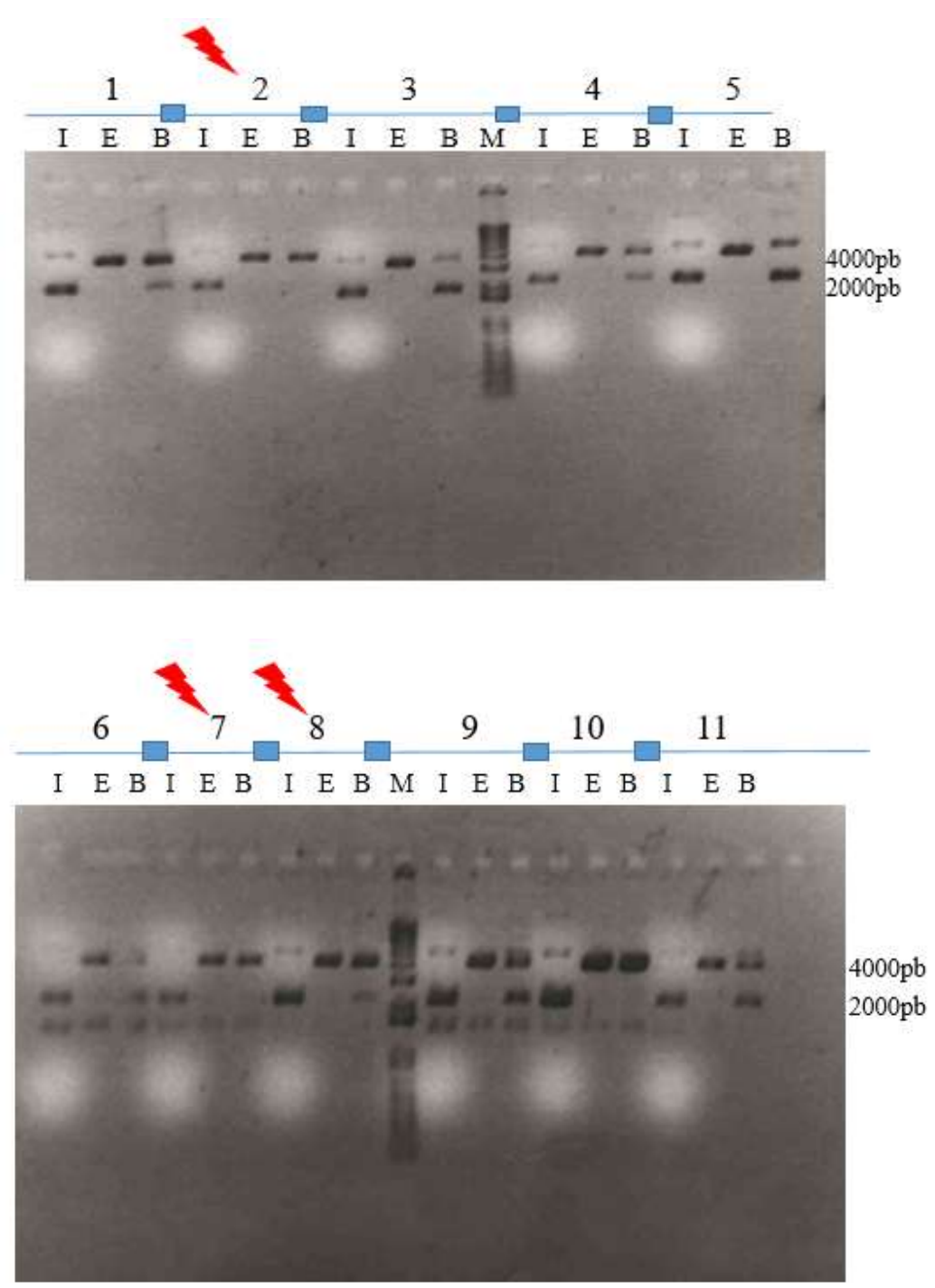

Figura 13. Digestão dos plasmídeos dos plasmídeos para a confirmação da clonagem do VH10. A disposição das amostras no gel segue a sequência, plasmídeo intacto (I), digestão EcoRI (E) e digestão com BsiWI (B). As setas (vermelho) indicam as amostras consideradas clones positivos após o screening.

As amostras que apresentavam as digestões mais confiáveis, como a clara observação da linearização $(4.151 \mathrm{pb})$ e a ausência de bandas extras, foram selecionadas e enviadas para sequenciamento Sanger.

$2^{\circ}$ Conjunto de clonagens

O plasmídeo resultante da primeira clonagem (VH10) serviu como vetor para as três clonagens restantes, já que apenas um pequeno fragmento referente ao domínio VH seria substituído, mantendo a CDR H3 e a cadeia VpreBJ. Dessa vez, os plasmídeos contendo o 
vetor e inserto foram digeridos com XmaI e BsiWI destacando a região citada acima e inseridos no vetor.
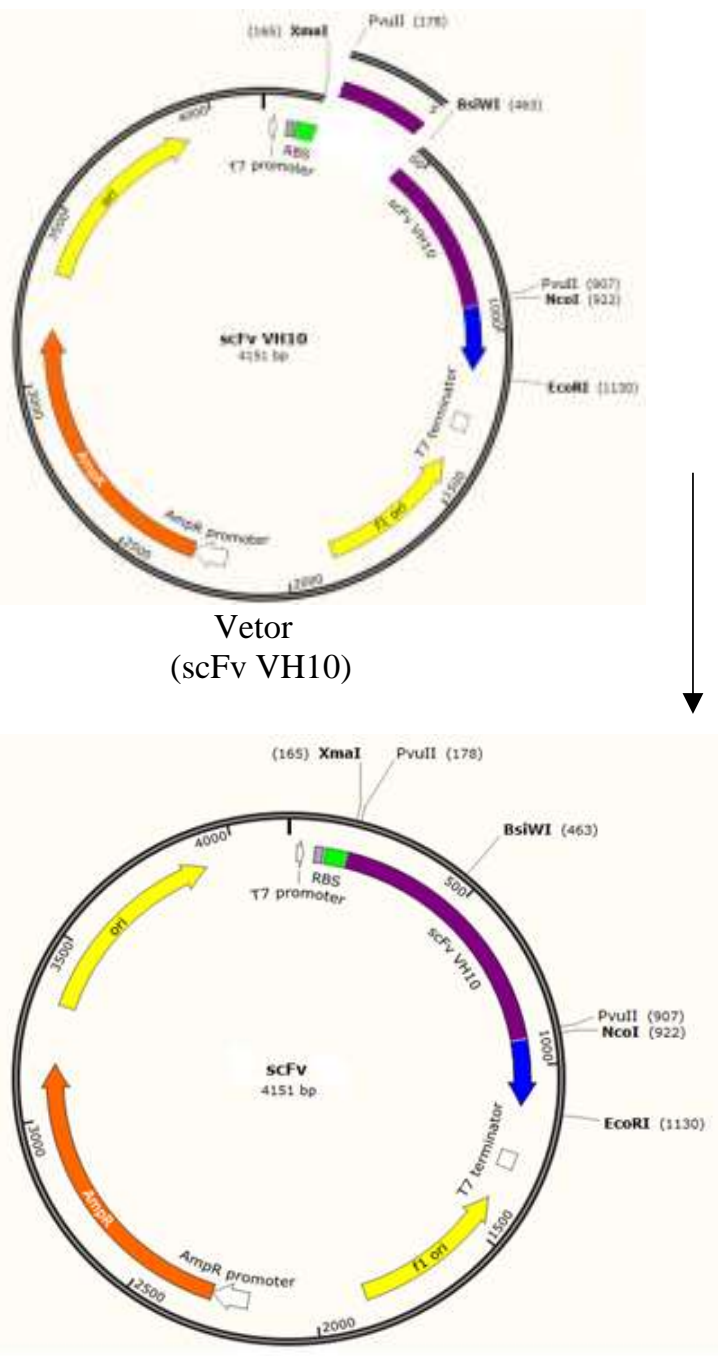

VH10-H24

(2 sítios de PvuII)

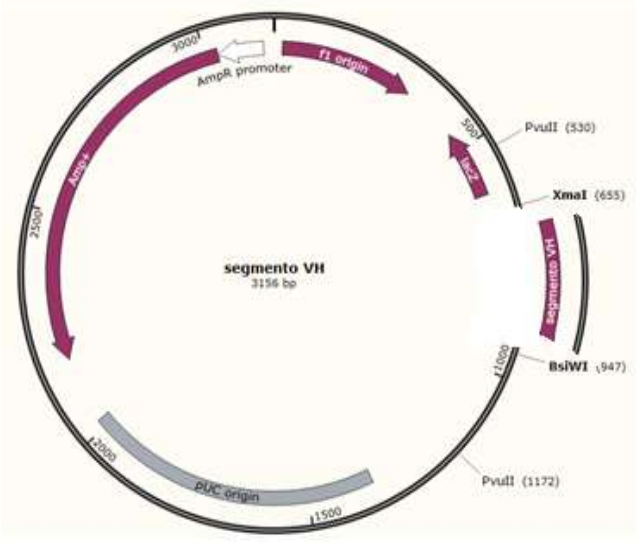

Plasmídeo comercial com os insertos de interesse

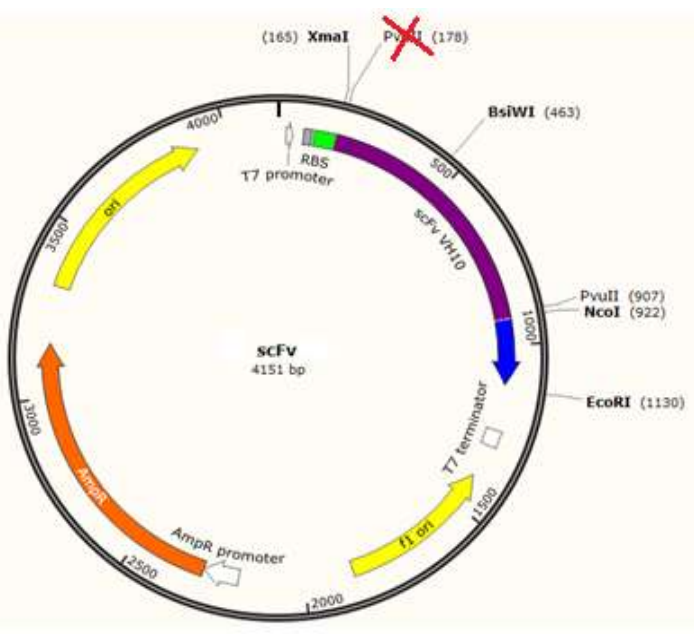

VH4 e VH4-H210

(1 sítio de PvuII)

Figura 14. Esquema do segundo conjunto digestões. Utilizou-se as enzimas XmaI e BsiWI para liberação do vetor e retirada do inserto. Diferenças no número sítios de PvuII foram utilizados como auxílio para confirmação por enzimas restrição.

Os plasmídeos foram digeridos com XmaI e BsiWI para liberação do vetor e retirada do segmento de interesse do plasmídeo comercial (Figura 14). O segmento gênico de interesse para a formação do scFv obtido foi então ligado ao vetor. Após a amplificação e purificação, o material passou por novas digestões para a confirmação da clonagem.

Dois perfis diferentes de plasmídeos foram obtidos após a clonagem. O plasmídeo VH10-H24 manteve os dois sítios de PvuII após a clonagem o que não permitiu a confirmação da digestão pela sua grande semelhança com o vetor. Já os plasmídeos VH4 e VH4-H210, após a clonagem apresentavam apenas um sítio de PvuII (Figura 14), tornando-se 
útil para a confirmação das clonagens em relação ao vetor, para descartar a presença do plasmídeo comercial onde estava o inserto, também foram feitas digestões com EcoRI já que um único sítio está presente nos clones VH4 e VH4-H210, porém nenhum sítio no plasmídeo comercial.

\section{VH4 (digerido com PvuII e EcoRI)}

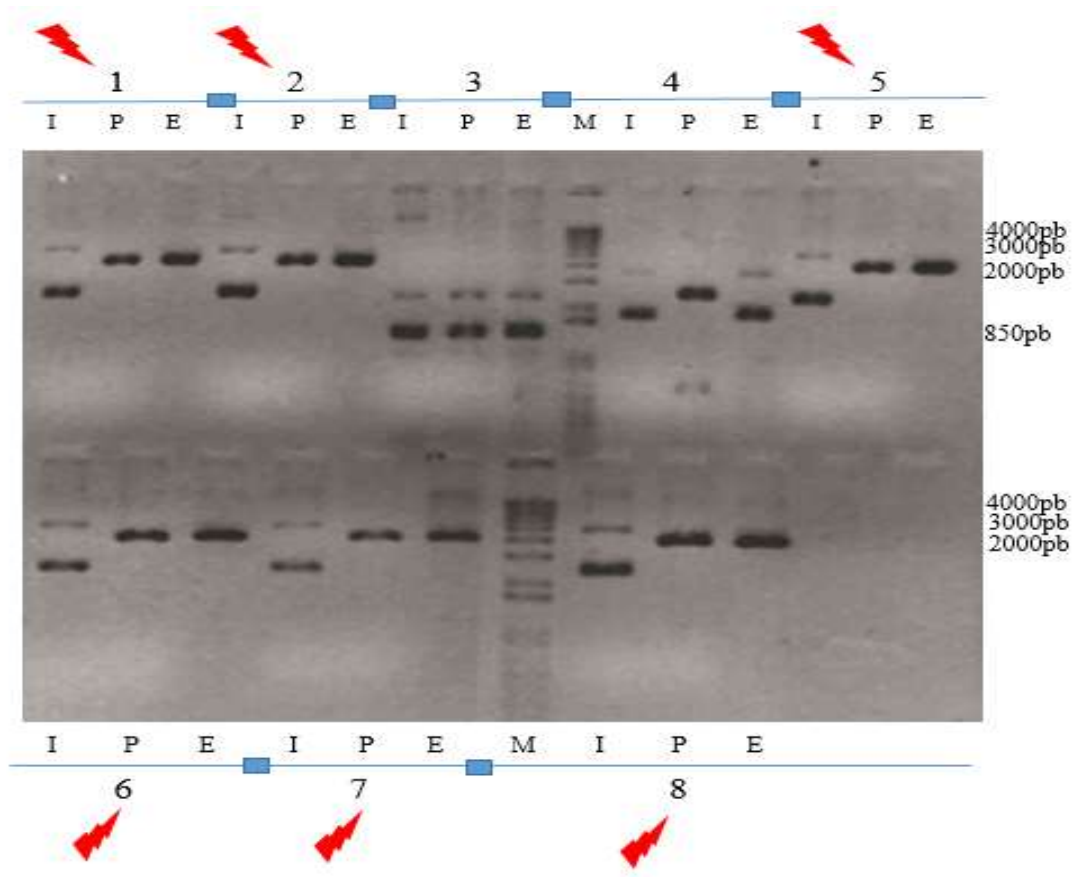

Figura 15. Digestão dos plasmídeos para a confirmação da clonagem de VH4. A disposição das amostras no gel segue a sequência, plasmídeo intacto (I), digestão PvuII PE) e digestão com EcoRI (E). As setas (vermelho) indicam as amostras consideradas clones positivos após o screening.

\section{VH4-H210 (digerido com PvuII e EcoRI)}

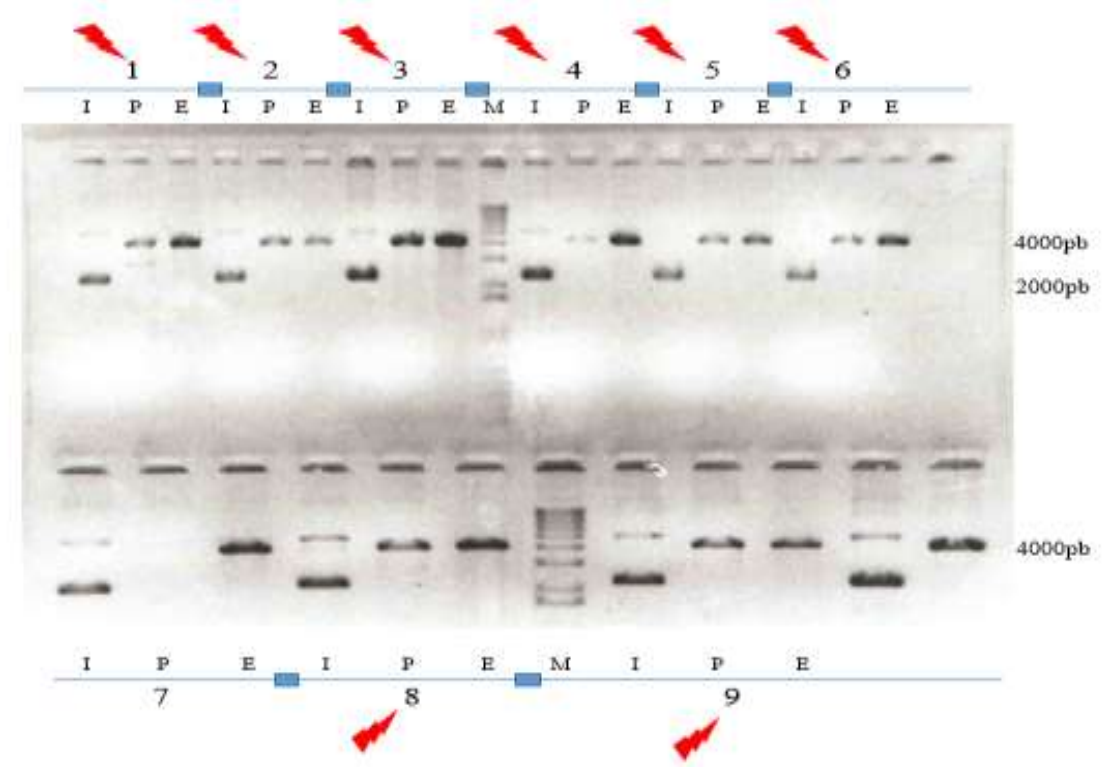


Figura 16. Digestão dos plasmídeos para a confirmação da clonagem de VH4-H210. A disposição das amostras no gel segue a sequência, plasmídeo intacto (I), digestão PvuII PE) e digestão com EcoRI (E). As setas (vermelho) indicam as amostras consideradas clones positivos após o screening.

Alguns clones do VH10-H24 foram enviados para sequenciamento sem screening prévio. E, alguns clones de VH4 e VH4-H210 que foram considerados clones positivos após o screening também foram enviados para sequenciamento Sanger.

\subsection{Resultado do sequenciamento (Sanger)}

A primeira clonagem resultou da liberação do vetor pela retirada de um segmento formador de scFv descartável para nossos propósitos e a inserção da nossa sequência formadora do $\mathrm{scFv}$ de cadeia $\mathrm{VH}$ germinal da família 10 e da cadeia leve conhecida como SLC por ser expressa apenas em células no estágio pré-B do desenvolvimento dos linfócitos B. A figura abaixo (Figura 17) mostra a inserção desse segmento no vetor que após a clonagem ficou flanqueado pelas sequências do peptídeo sinal formado por um domínio de fosfatase alcalina (PhoA) para transporte celular e pela proteína A para a purificação em coluna de IgG agarose, sequências estas, presentes apenas no vetor e não nos plasmídeos comerciais utilizados. Sendo então essas sequências expressas fusionadas ao scFv como um único polipeptídio.

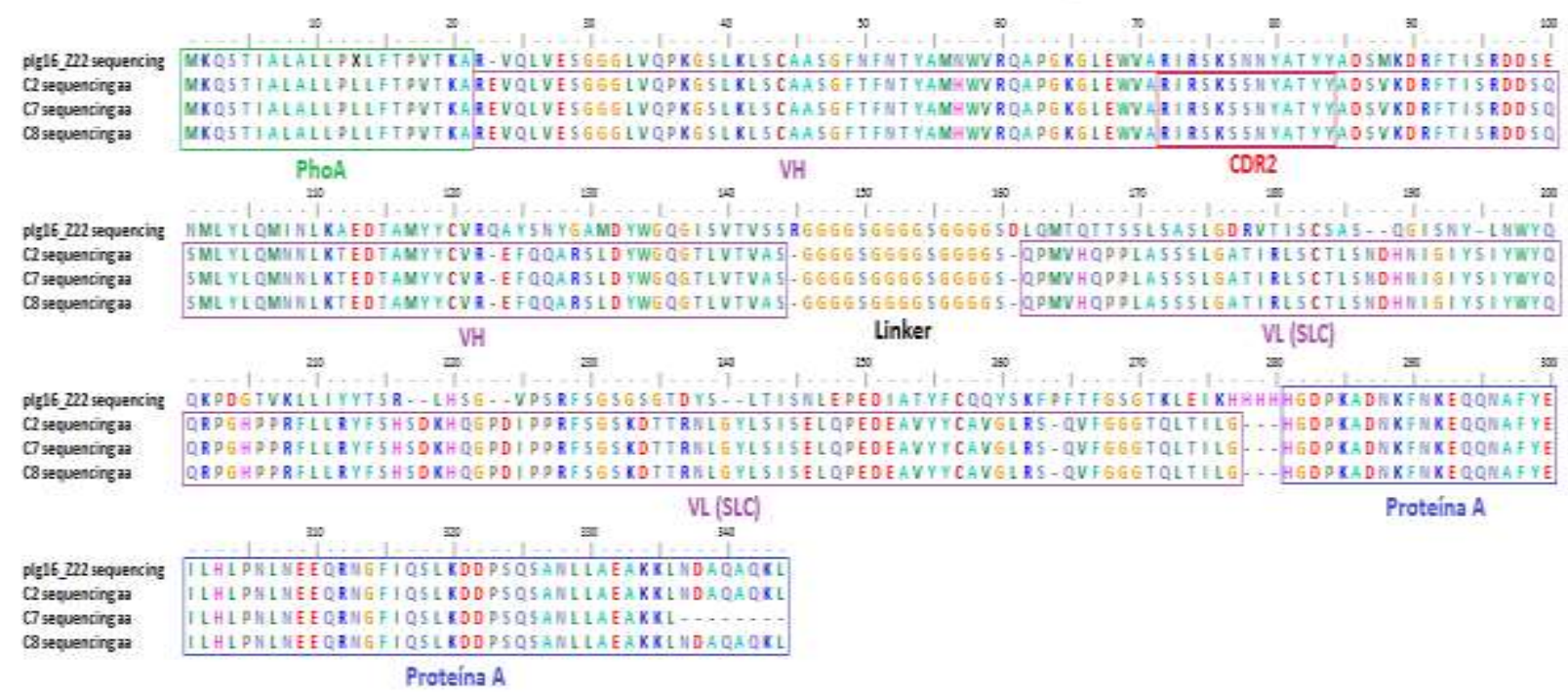

Figura 17. Alinhamento múltiplo (ClustalW/Bioedit) das sequências resultantes da primeira clonagem (C2, C7 e C8) após sequenciamento Sanger e do vetor (pIg16). Destacado em verde, PhoA; em lilás as cadeias VH e SLC formadoras do scFv com destaque para a CDR H2 em vermelho; em azul, a proteína A necessária para purificação. 
Para o segundo conjunto de clonagens o plasmídeo resultante da primeira clonagem foi utilizado como vetor. A inserção dos segmentos compreendia apenas o início da cadeia VH, sendo estes, VH4, VH4-H210 e VH10-H24 até o início da CDR H3 já que queríamos que esta região e a SLC estivessem conservadas entre as moléculas. Na figura abaixo (Figura 18), pode se observar as sequências de VH4 e VH10 originais e suas variantes após a troca das CDRs H2 e a confirmação das clonagens no vetor (VH10/C2 sequencing) já que as amostras estão flanqueadas pelos segmentos formadores do peptídeo sinal (PhoA) e da proteína A.

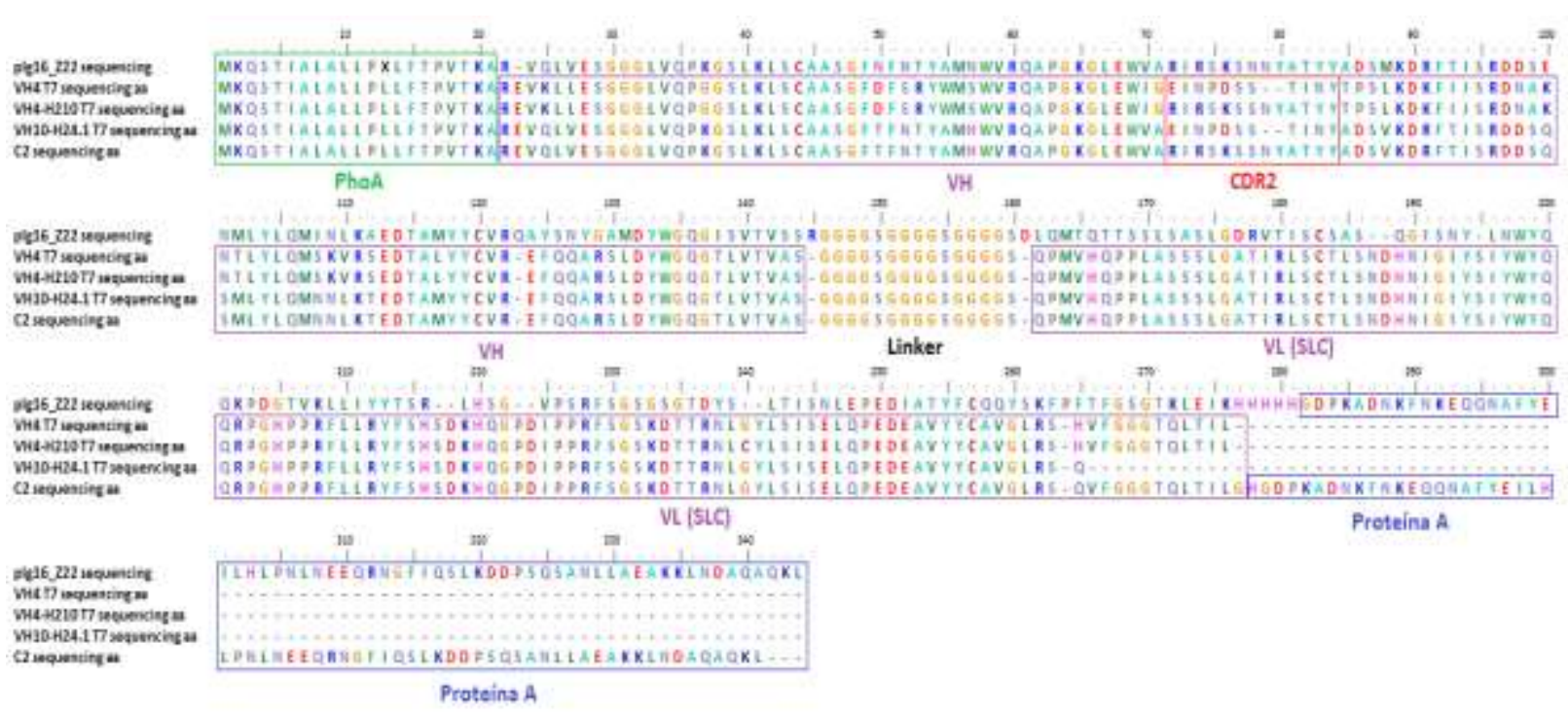

Figura 18. Alinhamento múltiplo (ClustalW/Bioedit) das sequências resultantes do segundo conjunto de clonagens (VH4; VH4-H210; VH10-H24). PhoA (verde), VH e VL (SLC), CDR2 (vermelho) e Proteína A (azul). Para comparação, a sequência do primeiro vetor (pIg16) e um clone da $1^{\circ}$ clonagem (C2) estão dispostos no alinhamento.

\subsection{EXPRESSÃO HETERÓLOGA EM E.coli}

O plasmídeo resultante da primeira clonagem (VH10) foi transformado em BL21(DE3) LysS e os procedimentos descritos no item 5.2.5.1 verificação de expressão foram executados. Pode-se observar que as amostras retiradas antes da indução apresentaram um certo grau de expressão do $\mathrm{scFv}$ de $\sim 37 \mathrm{kDa}$ e que após a indução pela adição de IPTG no meio de cultura a expressão do peptídeo foi aumentada significativamente (Figura 19), confirmando o funcionamento correto do vetor de expressão. $\mathrm{O}$ fato de mesmo na ausência de indução haver expressão do peptídeo não surpreende, pois o promotor forte T7, que faz parte da composição do vetor, apresenta esse 'vazamento' característico que pode ser inibido pela adição de glicose no meio (NOVY e MORRIS, 2001). 


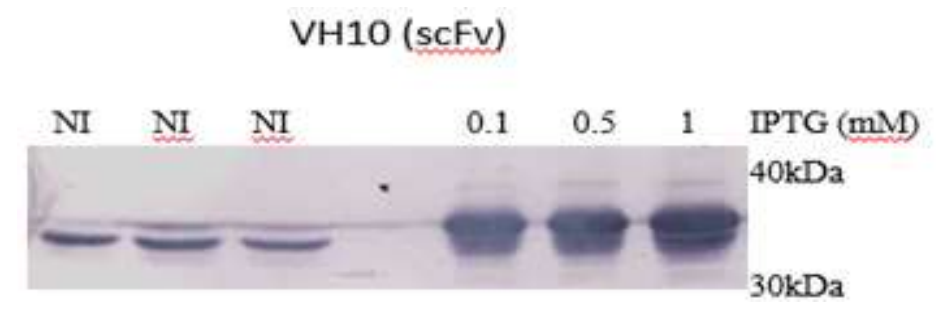

Figura 19. Western blot. Expressão de VH10 (scFv), amostras do extrato celular total de 3 colônias. Três primeiras amostras (esquerda) antes da indução com 1mM de IPTG (NI). As três amostras seguintes (direita) após a indução.

O mesmo procedimento foi seguido com os plasmídeos resultantes das clonagens do segundo conjunto de plasmídeos (VH4, VH4-H210 e VH10-H24). Nesse caso, dois géis foram feitos, sendo um corado com comassie $G$ e o outro utilizado para western blot. Pode ser claramente observado o aumento da expressão dos diferentes scFvs, com exceção do VH4H210, no qual após a indução não parece ter havido aumento significativo na expressão do polipeptídio. Também é possível observar degradação da proteína, porém em pouca quantidade, quando comparado com a banda não degradada (Figura19).

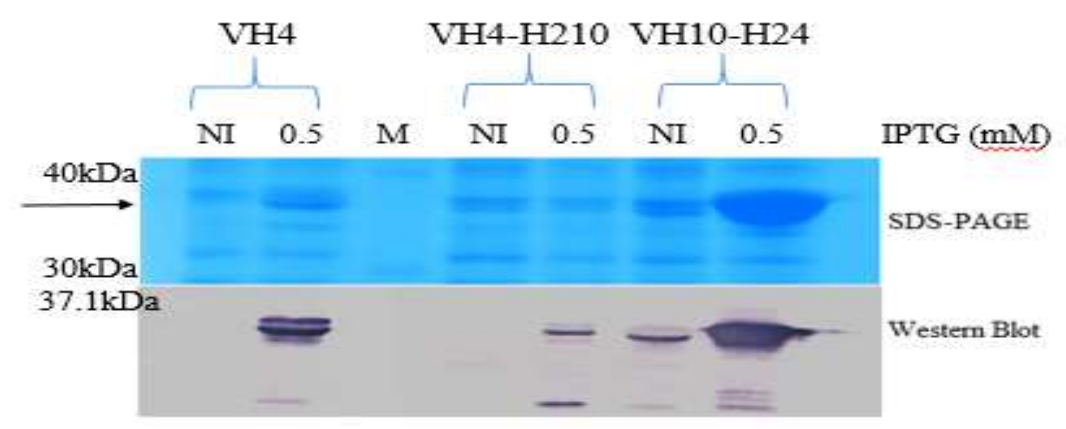

Figura 20..SDS-PAGE e Western blot do extrato total de cepas de BL21(DE3) LysS com os plasmídeos VH4, VH4-H210 e VH10-H24. Amostras antes da indução (NI) e depois da indução com IPTG são mostradas, assim como a posição do marcador $(\mathbf{M})$.

6.5 Expressão de proteínas solúveis

A produção de proteínas recombinantes expressas em E.coli em grande quantidade e na sua forma solúvel e funcional é uma limitação importante para a produção dessas proteínas. Em condições de sobrecarga de expressão as proteínas se agregam e formam os chamados corpos de inclusão. A formação dessas estruturas impede a recuperação dessas proteínas na sua forma nativa já que os procedimentos geralmente requerem condições desnaturantes, o que gera a necessidade de renaturação dessas proteínas (SØRENSEN e MORTENSEN, 2005). 
Novas abordagens experimentais têm sido testadas na tentativa de diminuir a formação de desses agregados através de alterações nas temperaturas de indução, concentração de IPTG, utilização de chaperonas, entre outros (SAN-MIGUEL, PÉREZ-BERMÚDEZ e GAVIDIA, 2013). Seguindo nessa linha, nós definimos diferentes concentrações e temperaturas para os sistemas de indução com o objetivo de obter de proteínas solúveis. Cada plasmídeo foi transformado em cepas de BL21(DE3) pLysS, crescidos em cultura e induzidos com $0.1 ; 0.2$ e $0.5 \mathrm{mM}$ de IPTG a temperaturas de $16^{\circ} \mathrm{C}$ e $37^{\circ} \mathrm{C}$.

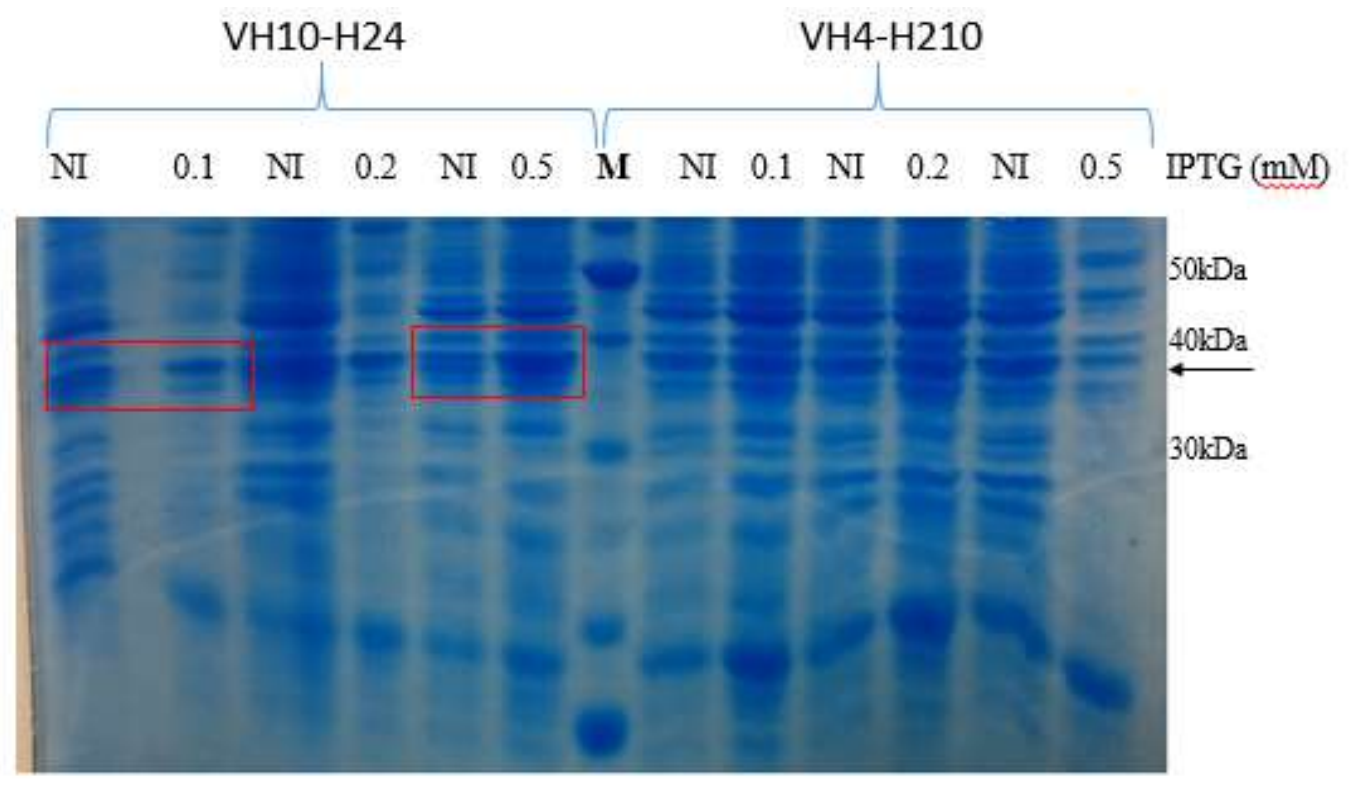

Figura 21. SDS-PAGE das amostras tratadas para obtenção de fração solúvel de proteínas após a indução em diferentes concentrações de IPTG a $16^{\circ} \mathrm{C}$. Na figura são indicados as amostras não induzidas (NI), o marcador (M) e as amostras induzidas com referência a concentração de IPTG uilizada.

$\mathrm{Na}$ análise do gel pôde-se obsevar um aumento de expressão na amostra de VH10-H24 induzida com $0.1 \mathrm{mM}$ e $0.5 \mathrm{mM}$ de IPTG a $16^{\circ} \mathrm{C}$ (Figura 21), a diferença de concentração entre as amostra 0.2mM e sua não induzida (NI) dificultou a avaliação. As amostras de VH4-H210 são bem semelhantes entre si , não sendo possível obeservar nenhum aumento de expressão entre os gupos induzidos e não induzidos (NI). Corroborando as observações feitas primeiramente no gel, o western blot (Figura 22), mostrou que todas as amostras de VH4H210 apresentaram algum grau de expressão de scFvs solúveis, com a expressão de proteína solúvel mais acentuada na indução de $0.5 \mathrm{mM}$ IPTG $\left(16^{\circ} \mathrm{C}\right)$. Note-se que esta figura está invertida com relação a figuras do gel das mesmas amostras acima.

As amostras do scFv VH4-H210 apresentaram pouquíssima expressão dessa proteína nessas condições, pode ser observado bandas na parte inferior da membrana das amostras 
induzidas, o que pode indicar degradação do material. Esse resultado para os scFvs e VH4H210 contradizem as expectativas do ensaio, pois tem sido mostrado que expressão de proteínas em E.coli em baixas temperaturas melhoram a solubilidade de proteínas difíceis de expressar na forma solúvel, levando a maior estabilidade e padrão de dobramento correto das moléculas e impedindo a formação de corpos de inclusão e diminuição da degradação, acontecimentos estes provavelmente relacionado com aumento da expressão de chaperonas em E.coli em baixas temperaturas (KHOW e SUNTRARACHUN, 2012).

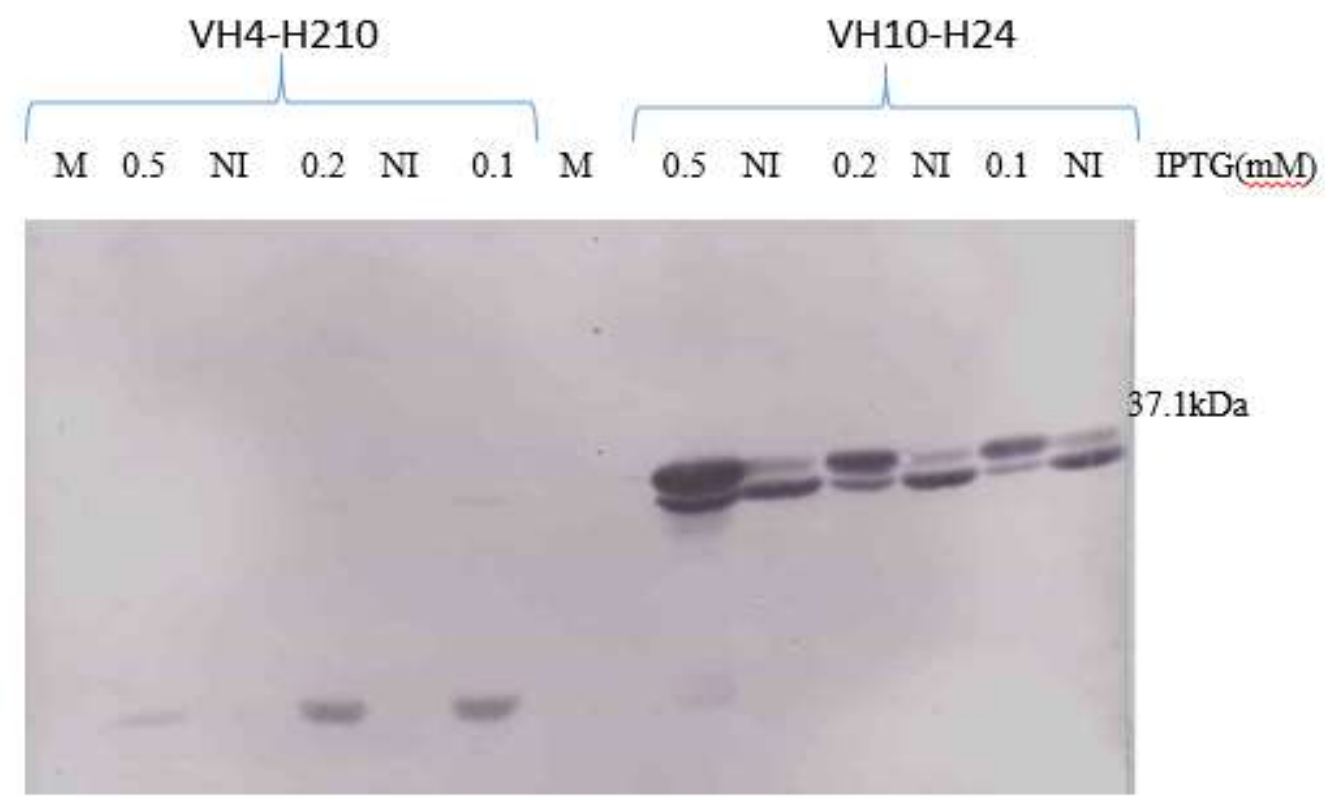

Figura 22. Western blot das amostras tratadas para obtenção de fração solúvel de proteínas após a indução em diferentes concentrações de IPTG a $16^{\circ} \mathrm{C}$.

As amostras de VH4 e VH4-VH10 foram induzidas em diferentes concentrações de IPTG a $37^{\circ} \mathrm{C}$. Pode-se observar na indução de $0.1 \mathrm{mM}$ do scFv VH4 houve aumento da expressão na altura da proteína alvo de $\sim 37 \mathrm{kDa}$, considerando-se a todas as bandas de proteína dessa amostra e de sua versão não induzida (NI) percebe-se que elas estão em concentrações equivalentes, o que facilia a constatação do aumento de expressão na altura esperada. Diferentemente, as outras amostras de VH4 e VH4-H210 não apresentam equivalência entre as concentrações das amostras induzidas e não induzidas o que prejudica a análise (Figura 22). Essas amostras induzidas são feitas em pequenas quantidades (25ml), dos quais apenas uma alíquota de $1 \mathrm{ml}$ foi utilizado para a obtenção da fração solúvel, o que indica a possível obtenção de grandes quantidades de proteína nos ensaios de produção em $500 \mathrm{ml}-1 \mathrm{~L}$ de meio de cultura. 

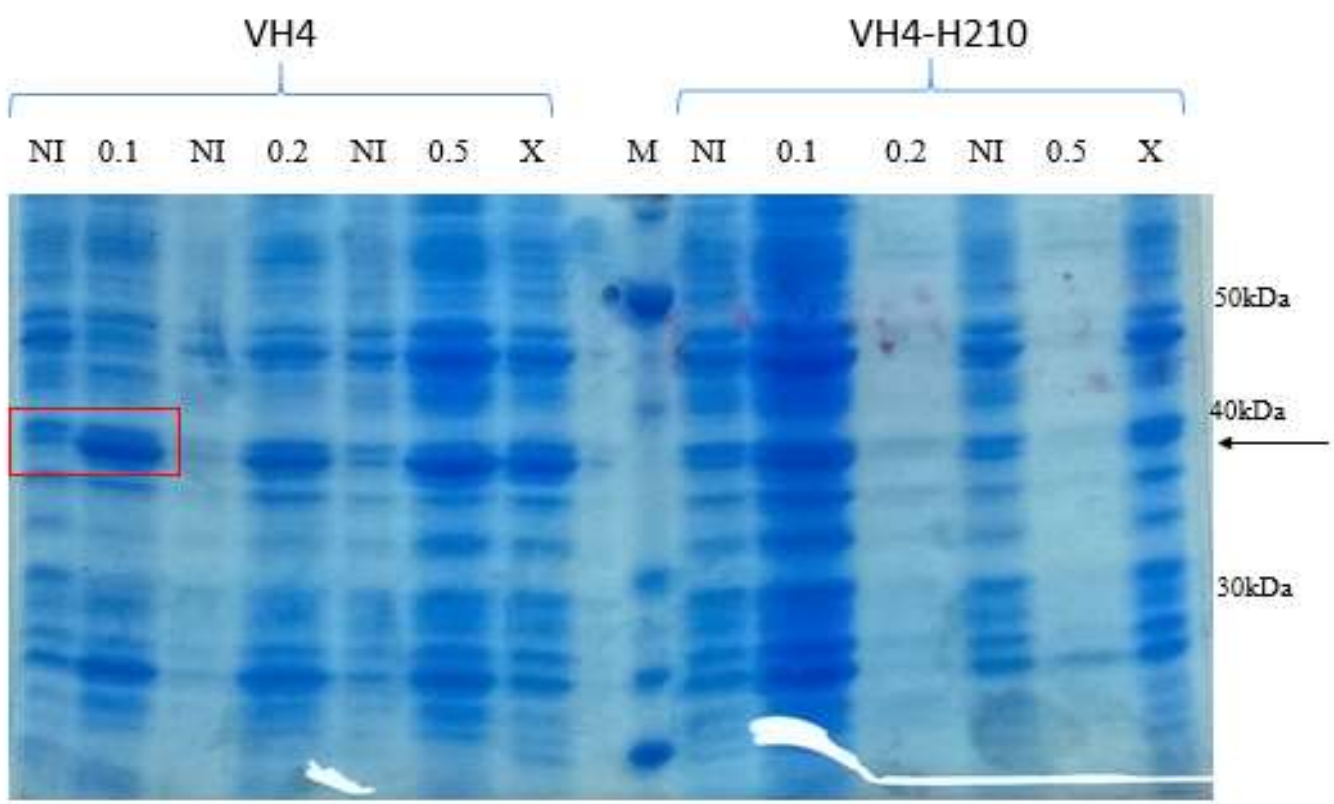

Figura 23. SDS-PAGE das amostras tratadas para obtenção de fração solúvel de proteínas após a indução em diferentes concentrações de IPTG a $37^{\circ} \mathrm{C}$.

Não foi possível testar até o momento, as construções do scFv VH10 para a produção de proteínas solúveis, uma série de tentativas de transformação do plasmídeo nas cepas de BL21 culivados LB ágar não resultaram em crescimento de colônias, fato estranho já que esse plasmídeo já timha sido transformado anterioremente e as células cultivadas normalmente. Após essas tentativas, foram feitos controles com placas com glicose e sem glicose levando-se em consideração que a expressão basal dessa proteína causada pelo 'vazamento' característicos na expressão poderia estar inibindo o crescimento dessas células (ROSANO e CECCARELLI, 2014), nenhuma melhora significativa foi observada. As poucas colônias crescidas não apresentavam bom crescimento quando inoculadas em meio de cultura. Dessa forma, alguns condições de transformação e crescimento terão de ser revistas para esse plasmídeo e cepa bacteriana.

\section{CONCLUSÃO E PERSPECTIVAS}

A construção de fragmentos de anticorpos como os scFvs que preservam funções específicas, como a especificidade antigênica, são ferramentas apropriadas para a investigação da interação antígeno-anticorpo, além de serem moléculas mais facilmente expressas em sistemas de expressão bacterianos.

As nossas moléculas recombinantes da família VH10 ligadas a uma cadeia leve que é expressa em células B em desenvolvimento visa simular o reconhecimento antigênico em um 
momento onde já se sabe que a auto-reatividade é utilizada como mecanismo de seleção. Isso faz com que haja a possibilidade de que famílias germinais de $\mathrm{VH}$ com sequências potencialmente auto-reativas sejam selecionadas positivamente compondo parte do repertório de células B que saem da medula para desempenhar a função de defesa.

Neste trabalho, além da clonagem desses segmentos gênicos em vetor de expressão bacteriana, eles foram expressos em cepas de BL21(DE3)pLysS com sucesso, com exceção da construção VH4-H210 que mesmo na análise do extrato total apresentou pouca expressão e certo grau de degradação. A produção também foi otimizada para a obtenção dessas proteínas na forma solúvel, sendo que as condições para duas construções foram estabelecidas: a construção VH10-H24 apresentou melhor produção na sua forma solúvel quando induzida a $16^{\circ} \mathrm{C}$ e $0,5 \mathrm{mM}$ de IPTG, enquanto a construção VH4 foi melhor expressa na sua forma solúvel a $37^{\circ} \mathrm{C}$ e $0,1 \mathrm{mM}$ de IPTG.

O estudo das interações anticorpo-antígeno de anticorpos auto-reativos, principalmente de anticorpos anti-DNA têm de ser melhor compreendido, pois estes anticorpos são importantes para o desenvolvimento de algumas doenças autoimunes. A clara compreensão dessa interação irá permitir com que abordagens terapêuticas específicas sejam desenvolvidas. Atualmente anticorpos anti-DNA capazes de hidrólise estão sendo estudados quanto a sua utilização terapêutica em canceres nos quais as células afetadas apresentam deficiências no reparo de DNA (HANSEN et al., 2012), o que confirma a importância desse conhecimento para diversas aplicações. 


\section{REFERÊNCIAS}

AFSHAR, R. et al. Regulation of IgH Gene Assembly : Role of the Intronic. The Journal of Immunology, v. 176, n. 4, p. 2439-2447, 15 fev. 2013.

AHMAD, Z. A. et al. scFv Antibody: Principles and Clinical Application. Clinical and Developmental Immunology, v. 2012, p. 1-15, 2012.

AKIRA, S. et al. Pathogen recognition and innate immunity. Cell, v. 124, p. 783-801, 2006.

ARBUCKLE, M. R. et al. Development of anti-dsDNA autoantibodies prior to clinical diagnosis of systemic lupus erythematosus. Scandinavian Journal of Immunology, v. 54, n. 1-2, p. 211-219, 2001.

BILGIMOL, J. C. et al. An Overview of the Parameters for Recombinant Protein Expression in Escherichia coli. Cell Science \& Therapy, v. 6, n. 4, 2015.

BOEHM, T. Evolution of Vertebrate Immunity. Current Biology, v. 22, n. 17, p. R722R732, set. 2012.

BOES, M. et al. Accelerated development of $\operatorname{IgG}$ autoantibodies and autoimmune disease in the absence of secreted IgM. Proceedings of the National Academy of Sciences, v. 97, n. 3, p. 1184-1189, 1 fev. 2000.

BRADL, H. et al. Interaction of Murine Precursor B Cell Receptor with Stroma Cells Is Controlled by the Unique Tail of 5 and Stroma Cell-Associated Heparan Sulfate. The Journal of Immunology, v. 171, n. 5, p. 2338-2348, 1 set. 2003.

DE BONO, B.; MADERA, M.; CHOTHIA, C. VH Gene Segments in the Mouse and Human Genomes. Journal of Molecular Biology, v. 342, n. 1, p. 131-143, set. 2004.

GAUTHIER, L. et al. Galectin-1 is a stromal cell ligand of the pre-B cell receptor (BCR) implicated in synapse formation between pre-B and stromal cells and in pre-BCR triggering. Proceedings of the National Academy of Sciences, v. 99, n. 20, p. 13014-13019, 2002.

HANSEN, J. E. et al. Targeting Cancer with a Lupus Autoantibody. Science Translational Medicine, v. 4, n. 157, p. 157ra142-157ra142, 24 out. 2012.

HARA, T. et al. Identification of IL-7-Producing Cells in Primary and Secondary Lymphoid Organs Using IL-7-GFP Knock-In Mice. The Journal of Immunology, v. 189, n. 4, p. 15771584, 15 ago. 2012.

HSU, H. J. et al. Antibody variable domain interface and framework sequence requirements for stability and function by high-throughput experiments. Structure, v. 22, n. 1, p. 22-34, jan. 2014.

ISENBERG, D. A. et al. Fifty years of anti-ds DNA antibodies: Are we approaching journey's end? Rheumatology, v. 46, n. 7, p. 1052-1056, 2007.

JACKSON, K. J. L. et al. Exonuclease activity and P nucleotide addition in the generation of 
the expressed immunoglobulin repertoire. BMC immunology, v. 5, p. 19, 2004.

JUNG, D. et al. Mechanism and Control of V(d)j Recombination at the Immunoglobulin Heavy Chain Locus. Annual Review of Immunology, v. 24, n. 1, p. 541-570, 2006.

KEENAN, R. A et al. Censoring of autoreactive B cell development by the pre-B cell receptor. Science, v. 321, n. 5889, p. 696-699, 2008.

KHOW, O.; SUNTRARACHUN, S. Strategies for production of active eukaryotic proteins in bacterial expression system. Asian Pacific Journal of Tropical Biomedicine, v. 2, n. 2, p. 159-162, 2012.

KIL, L. P. et al. Surrogate light chain expression beyond the pre-B cell stage promotes tolerance in a dose-dependent fashion. Journal of Autoimmunity, v. 57, p. 30-41, 2015.

KÖHLER, F. et al. Autoreactive B Cell Receptors Mimic Autonomous Pre-B Cell Receptor Signaling and Induce Proliferation of Early B Cells. Immunity, v. 29, n. 6, p. 912-921, 2008.

KONTERMANN, R. Antibody Engineering. Berlin, Heidelberg: Springer Berlin Heidelberg, 2010. v. 1

KUNIK, V.; PETERS, B.; OFRAN, Y. Structural Consensus among Antibodies Defines the Antigen Binding Site. PLoS Computational Biology, v. 8, n. 2, p. e1002388, 23 fev. 2012.

LEBIEN, T. W.; TEDDER, T. F. B lymphocytes: how they develop and function. Blood, v. 112, n. 5, p. 1570-1580, 1 set. 2008.

LUCKHEERAM, R. V. et al. CD4+T Cells: Differentiation and Functions. Clinical and Developmental Immunology, v. 2012, p. 1-12, 2012.

MÅRTENSSON, I.-L. et al. The pre-B cell receptor checkpoint. FEBS Letters, v. 584, n. 12, p. 2572-2579, 18 jun. 2010.

MINEGISHI, Y. et al. Mutations in the Human 5/14.1 Gene Result in B Cell Deficiency and Agammaglobulinemia. Journal of Experimental Medicine, v. 187, n. 1, p. 71-77, 5 jan. 1998.

MORSTADT, L. et al. Engineering and characterization of a single chain surrogate light chain variable domain. Protein Science, v. 17, n. 3, p. 458-465, mar. 2008.

NELSON, A. L. Antibody fragments. mAbs, v. 2, n. 1, p. 77-83, 27 jan. 2010.

NORTH, B.; LEHMANN, A.; DUNBRACK, R. L. A New Clustering of Antibody CDR Loop Conformations. Journal of Molecular Biology, v. 406, n. 2, p. 228-256, fev. 2011.

NOVY, R.; MORRIS, B. Use of glucose to control basal expression in the pET System. inNovations, v. 13, n. 1, p. 13-15, 2001.

PARKER, M. J. et al. The pre-B-cell receptor induces silencing of VpreB and $\lambda 5$ transcription. The EMBO Journal, v. 24, n. 22, p. 3895-3905, 16 nov. 2005.

PERSSON, H. et al. CDR-H3 diversity is not required for antigen recognition by synthetic 
antibodies. Journal of Molecular Biology, v. 425, n. 4, p. 803-811, 2013.

REPASKY, J. A. E. et al. Mutational analysis of terminal deoxynucleotidyltransferasemediated $\mathrm{N}$-nucleotide addition in $\mathrm{V}(\mathrm{D}) \mathrm{J}$ recombination. Journal of immunology (Baltimore, Md. : 1950), v. 172, n. 9, p. 5478-88, 1 maio 2004.

ROSANO, G. L.; CECCARELLI, E. A. Recombinant protein expression in Escherichia coli: advances and challenges. Frontiers in Microbiology, v. 5, n. APR, p. 1-17, 17 abr. 2014.

SAN-MIGUEL, T.; PÉREZ-BERMÚDEZ, P.; GAVIDIA, I. Production of soluble eukaryotic recombinant proteins in $\mathrm{E}$. coli is favoured in early log-phase cultures induced at low temperature. SpringerPlus, v. 2, n. 1, p. 89, 2013.

SHIMIZU, T. et al. VpreB1/VpreB2/ 5 Triple-Deficient Mice Show Impaired B Cell Development but Functional Allelic Exclusion of the IgH Locus. The Journal of Immunology, v. 168, n. 12, p. 6286-6293, 15 jun. 2002.

SONG, Y.-C. et al. Arginines in the CDR of anti-dsDNA autoantibodies facilitate cell internalization via electrostatic interactions. European Journal of Immunology, v. 38, n. 11, p. 3178-3190, nov. 2008.

SØRENSEN, H. P.; MORTENSEN, K. K. Soluble expression of recombinant proteins in the cytoplasm of Escherichia coli. Microbial cell factories, v. 4, n. 1, p. 1, 4 jan. 2005.

TANNER, J. J.; KOMISSAROV, A. A.; DEUTSCHER, S. L. Crystal structure of an antigenbinding fragment bound to single-stranded DNA. Journal of molecular biology, v. 314, n. 4, p. 807-22, 2001.

TERPE, K. Overview of bacterial expression systems for heterologous protein production: From molecular and biochemical fundamentals to commercial systemsApplied Microbiology and Biotechnology, 22 set. 2006. Disponível em: <http://link.springer.com/10.1007/s00253-006-0465-8>

TONEGAWA, S. Somatic generation of immune diversity. Bioscience Reports, v. 8, n. 1, p. 3-26, fev. 1988.

WEI, C.; ZEFF, R.; GOLDSCHNEIDER, I. Murine pro-B cells require IL-7 and its receptor complex to up-regulate IL-7R alpha, terminal deoxynucleotidyltransferase, and c mu expression. Journal of immunology (Baltimore, Md. : 1950), v. 164, n. 4, p. 1961-70, 15 fev. 2000.

WHITCOMB, E. A. et al. Germline structure and differential utilization of Igha and Ighb VH10 genes. Journal of immunology (Baltimore, Md.: 1950), v. 162, n. 3, p. 1541-50, 1 fev. 1999.

WILKINSON, I. C. et al. High Resolution NMR-based Model for the Structure of a scFv-IL-1 Complex: POTENTIAL FOR NMR AS A KEY TOOL IN THERAPEUTIC ANTIBODY DESIGN AND DEVELOPMENT. Journal of Biological Chemistry, v. 284, n. 46, p. 31928-31935, 13 nov. 2009. 
ZHANG, X.; STUDIER, F. W. Mechanism of inhibition of bacteriophage T7 RNA polymerase by T7 lysozyme. Journal of Molecular Biology, v. 269, n. 1, p. 10-27, maio 1997. 